\title{
WestVirginiaUniversity
}

THE RESEARCH REPOSITORY @ WVU

Graduate Theses, Dissertations, and Problem Reports

2013

\section{Africa, Appalachia, and acculturation: The history of bluegrass music}

Charles W. Perryman

West Virginia University

Follow this and additional works at: https://researchrepository.wvu.edu/etd

\section{Recommended Citation}

Perryman, Charles W., "Africa, Appalachia, and acculturation: The history of bluegrass music" (2013). Graduate Theses, Dissertations, and Problem Reports. 298.

https://researchrepository.wvu.edu/etd/298

This Dissertation is protected by copyright and/or related rights. It has been brought to you by the The Research Repository @ WVU with permission from the rights-holder(s). You are free to use this Dissertation in any way that is permitted by the copyright and related rights legislation that applies to your use. For other uses you must obtain permission from the rights-holder(s) directly, unless additional rights are indicated by a Creative Commons license in the record and/ or on the work itself. This Dissertation has been accepted for inclusion in WVU Graduate Theses, Dissertations, and Problem Reports collection by an authorized administrator of The Research Repository @ WVU.

For more information, please contact researchrepository@mail.wvu.edu. 
AFRICA, APPALACHIA, AND ACCULTURATION:

THE HISTORY OF BLUEGRASS MUSIC

\author{
by \\ Charles W. Perryman \\ D.M.A Research Project submitted to the College of Creative Arts \\ at West Virginia University \\ in partial fulfillment of the requirements \\ for the degree of
}

Doctor of Musical Arts

in

Composition

Approved by

John Beall, Committee Chairperson

Christopher Wilkinson

David Taddie

Andrew Kohn

Gerald Habarth

School of Music

Morgantown, West Virginia

2013

Keywords: Bluegrass, History, African-American music, Appalachian music, Country Music

Copyright 2013 Charles W. Perryman 
ABSTRACT

\title{
AFRICA, APPALACHIA, AND ACCULTURATION: THE HISTORY OF BLUEGRASS MUSIC
}

\author{
by Charles W. Perryman
}

Though primarily associated with white Southerners, bluegrass music is actually the product of over three hundred years of black and white musical interaction that occurred in the American Southeast. This document begins by reviewing the first complete definition of bluegrass music written by Mayne Smith. It then proceeds to explore the history of cross cultural exchanges in the South, particularly in the Appalachian Mountains, that began when the first slaves were brought to the New World. In the South, these interactions created the folk music that would eventually develop into country music and later bluegrass in the twentieth century. Black musical styles also directly influenced the father of bluegrass, Bill Monroe, especially through his contact with the blues musician Arnold Shultz. The banjo playing of Earl Scruggs, an essential element of bluegrass, also owes a significant debt to African-American banjo styles found in Scruggs's native region of North Carolina. 


\section{DEDICATION}

This paper is dedicated to the memory of my grandfather, Charles E. Perryman, Sr., the first bluegrass fiddle player I ever knew. My love of music began during those family jam sessions that happened without fail every holiday, reunion, and get-together. The band hasn't been the same without you. 


\section{ACKNOWLEDGMENTS}

There are several people I would like to thank for helping make this document possible. First, my research advisor Christopher Wilkinson, thank you for the guidance and encouragement you gave me throughout this project. Without your expertise, advice, and occasional whip-cracking, I would probably still be writing this paper. Thanks also to my graduate committee members Andrew Kohn, David Taddie, and Gerald Habarth. Your excellent suggestions no doubt strengthened and improved my final product and left me with something I can be proud of for a long time.

I would especially like to thank my teacher John Beall. You have helped me grow so much as a composer and musician over the past few years and I hope that one day I can be for my students the kind of teacher that you have been for me. Thank you so much for your help with this paper and for everything else.

I would also like to thank Amy McCann Toeller for spending hours upon hours across a table from me in the library and for making me work when I didn't want to work, Chris Toeller for keeping me grounded and helping me blow off steam, Kate Altizer for reading draft after terrible draft and for being the best friend a guy could ask for, and Travis Stimeling for all the advice and for helping me prepare for my defense. I also want to thank my fiancée April Angilletta for always listening to me when I needed it and for all of those four-hour drives you made to West Virginia. You are an amazing partner and friend.

Finally, thank you to my parents Susan Perryman and Charlie Perryman. Your love and support have always meant so much to me and I am lucky to have both of you in my life. I couldn't have done any of this without you. Thank you! 


\section{TABLE OF CONTENTS}

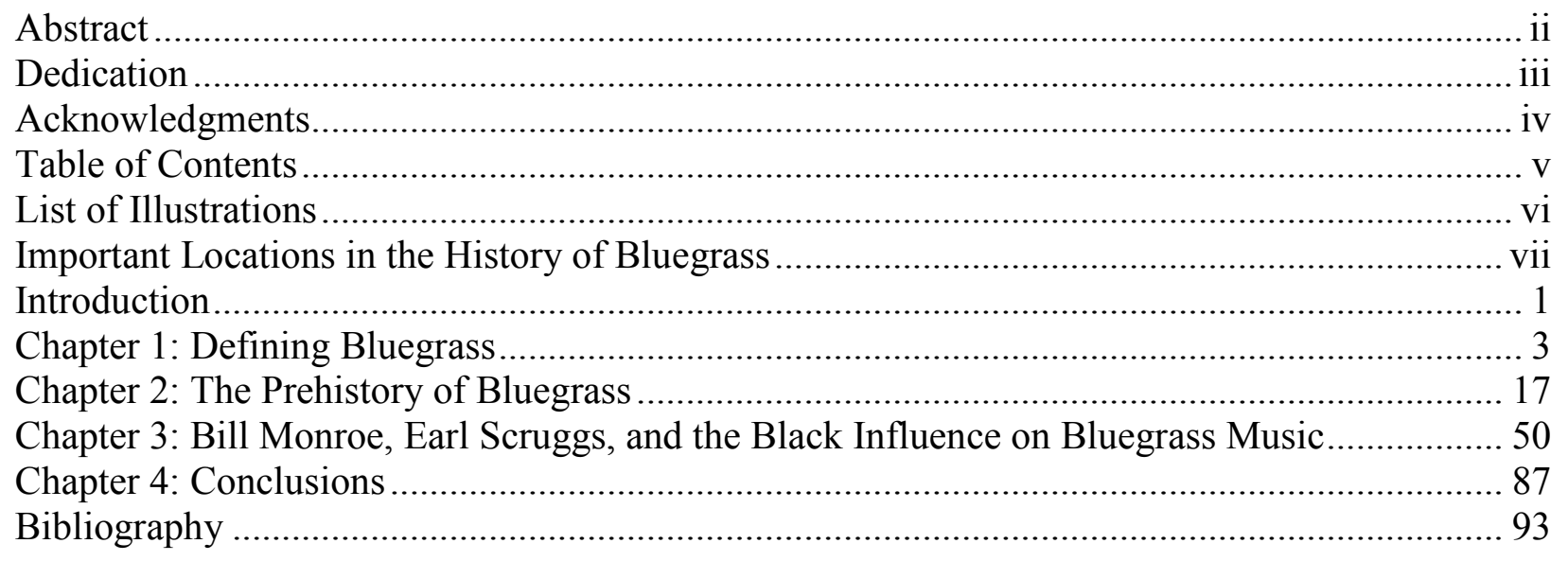




\section{LIST OF ILLUSTRATIONS}

\section{Images}

Important Locations in the History of Bluegrass vii

The Naked Mountain Boys Bluegrass Band

Musical Examples

Ex. 2.1: Dorian mode built on $\mathrm{G}$ .38

Ex. 2.2: Blues scale built on $\mathrm{G}$

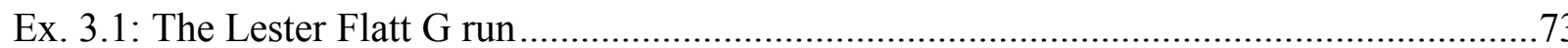

Ex. 3.2: Two Scruggs banjo rolls: forward roll and backward roll

Ex. 3.3: Two Scruggs banjo rolls: alternating thumb and reverse roll 


\section{IMPORTANT LOCATIONS IN THE HISTORY OF BLUEGRASS ${ }^{1}$}

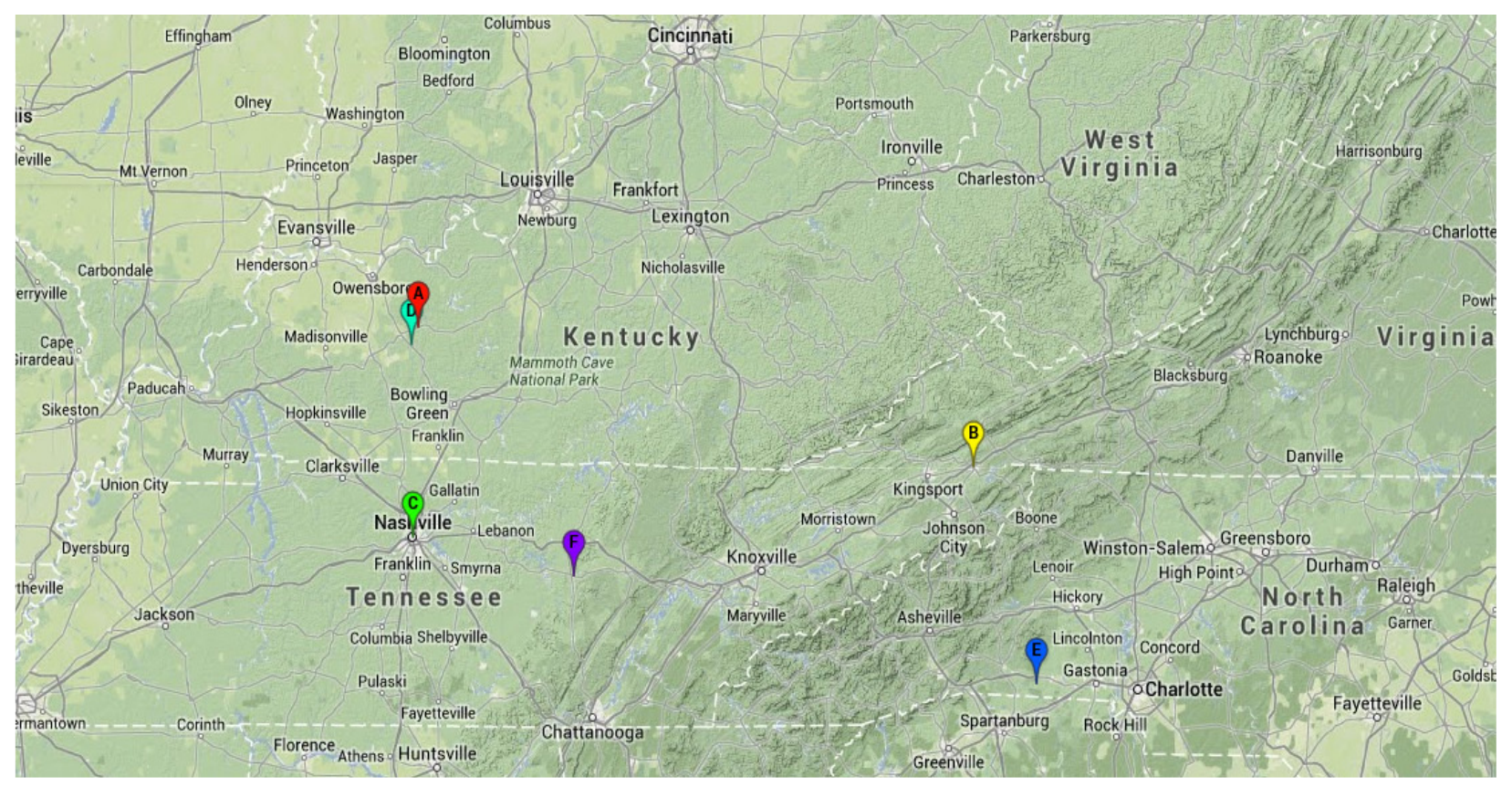

\section{Map Key}

A. Rosine, Kentucky. The birthplace of Bill Monroe.

B. Bristol, Tennessee. Location of the Bristol Sessions, the first commercial country music recording session. Later, Flatt, Scruggs, and the Foggy Mountain Boys broadcast out of here.

C. Nashville, Tennessee. The center of country music and the location of the Grand Ole Opry.

D. Cromwell, Kentucky. The likely birthplace of Arnold Shultz, a major influence on Bill Monroe.

E. Flint Hill Community, North Carolina. Birthplace of Earl Scruggs.

F. Sparta, Tennessee. Birthplace of Lester Flatt.

\footnotetext{
${ }^{1}$ Important Locations in the History of Bluegrass [map], 2013, Scale undetermined; generated by Charles Perryman; using "Google Map Engine Lite."

$<$ https://mapsengine.google.com/map/edit?mid=zgSlTPps4Uig.komAbeIW4heQ> 


\section{INTRODUCTION}

On the surface, bluegrass music is a style of country music heavily influenced by Appalachian folk music. As with almost all Appalachian folk music, the typical ensemble is a four- to seven-piece band made up of non-electrified string instruments. Many bluegrass songs are taken directly from the Appalachian folk repertoire and those that are original compositions show many of the melodic and rhythmic trademarks of the tradition. Bluegrass musicians, perhaps more so than in any other style of country music, are in constant contact with the communities of Appalachia and most of the musicians are from the region and frequently play there. These musicians and their audience are almost exclusively white, and it is undeniable that bluegrass music owes a great deal to the musical traditions of white Appalachians.

It is equally irrefutable that bluegrass music shares a great deal in common with black musical styles such as jazz and the blues. Group improvisation, alternating solos, and swing are just some of the musical features that jazz, the blues, and bluegrass share. The banjo, an instrument which is inextricably linked to the bluegrass sound, is African in origin. Bluegrass singing was influenced by the blues, black field hollers, and African-American Psalm singing. The African, particularly West African, influence on bluegrass is perhaps more surprising, but is just as essential as the European influence.

This study explores these two distinct strains of influence throughout the history (and pre-history) of bluegrass music. An examination of the musical characteristics of the style, the history of the music, the instruments, the playing and singing style, will reveal that the style has 
roots in both West African and European cultures. These various elements will be traced from their origins in their respective cultures through the development of Appalachian folk music in the late nineteenth century to the emergence of bluegrass in the 1940s. It is my intention to explore how Bluegrass developed out of a synthesis of musical traditions that have their roots in European and West African cultures.

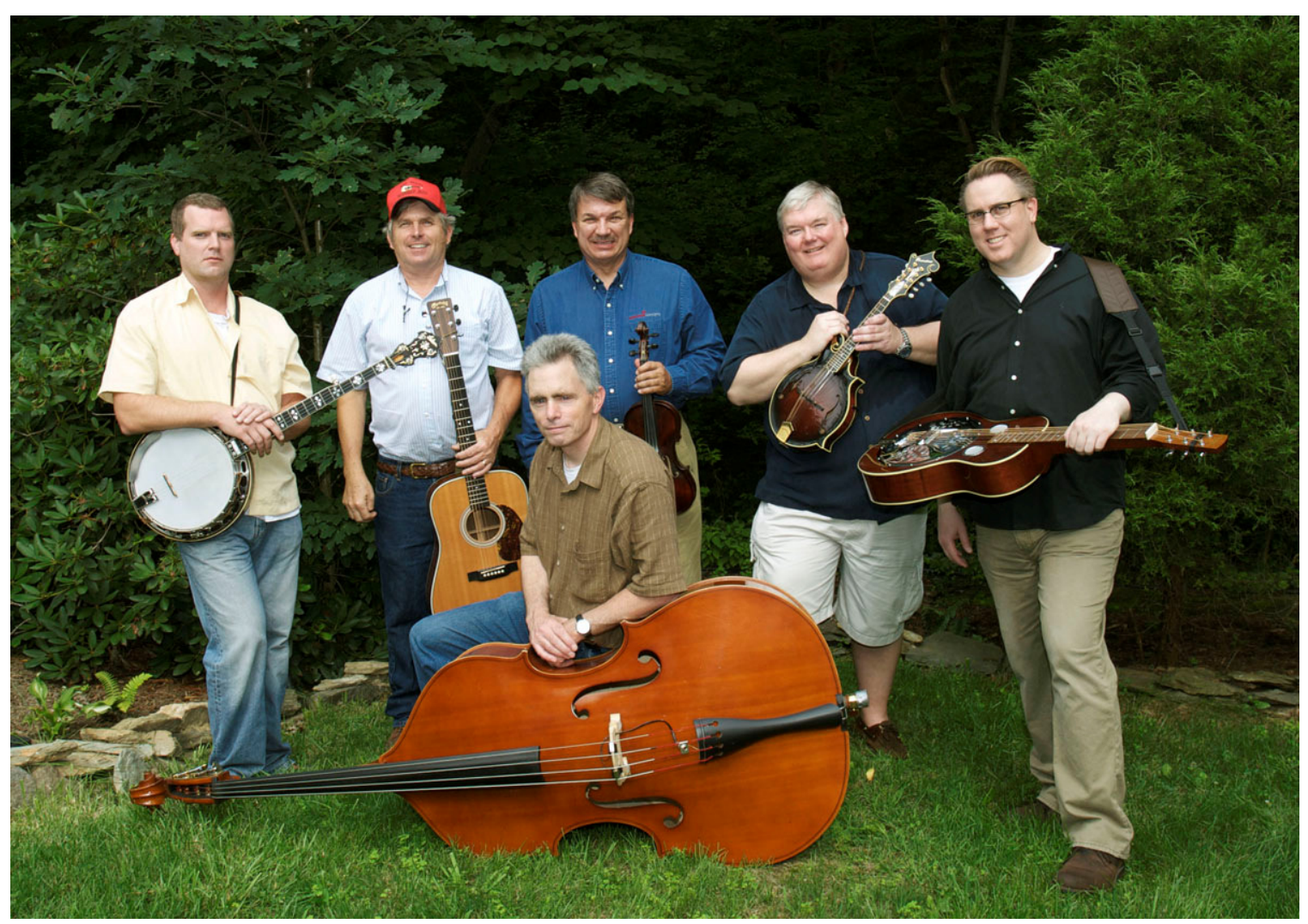

The Naked Mountain Boys Bluegrass Band ${ }^{2}$

This band, from northern Virginia, consists of the six standard bluegrass instruments.

From left to right those instruments are: the five-string banjo, steel string guitar, upright bass, fiddle, mandolin, and the resonator guitar or dobro.

\footnotetext{
${ }^{2}$ Used with permission of the Naked Mountain Boys and John Burns.
} 


\section{CHAPTER 1}

\section{DEFINING BLUEGRASS}

Kentucky-born mandolin player Bill Monroe first came to the attention of the American public when the Grand Old Opry began broadcasting his band's old-fashioned sound in $1939 .^{3}$ This style of country music remained unnamed even after Monroe's band acquired its classic line-up (including Earl Scruggs) in $1945 .^{4}$ In fact, it was not until 1957, the year in which Ralph Rinzler wrote the liner notes to American Banjo Scruggs Style, that the term "bluegrass" was first seen in print. ${ }^{5}$ The name was first used by fans who preferred the older, purely acoustic sound to that of modern, electrified contemporary country music. Bluegrass musicians themselves were hesitant to adopt the label perhaps because they were afraid it would be artistically and commercially limiting. ${ }^{6}$

Bluegrass is well known today mostly because it was discovered by people who saw it not only as a subset of country music but also as a new musical style with roots in traditional Appalachian music. These new fans were young urban intellectuals who considered bluegrass an authentic form of expression that stood in contrast to the popular music of the time. For them this was the music of poor, working class, rural Americans from a simpler and more cohesive society than their own. ${ }^{7}$

\footnotetext{
${ }^{3}$ Richard Crawford, America's Musical Life: A History. (New York: W. W. Norton, 2001) 741.

${ }^{4}$ The birth of bluegrass is discussed in detail in Chapter 3.

${ }^{5}$ Cf. Ralph Rinzler, liner notes to American Banjo Scruggs Style, Various Artists, Smithsonian Folkways SFW40037, CD, 1990.

${ }^{6}$ Neil V. Rosenberg, Bluegrass: A History. (Chicago: University of Illinois Press, 1985) 11.

${ }^{7}$ Rosenberg, 13.
} 
In reality though, bluegrass, which takes it name from Monroe's commercially successful band The Blue Grass Boys, was popular country music. It was initially popular in the rural upland south, particularly in the central Appalachian mountains, in the decade following the Second World War. Its audience consisted of rural working class people. It was not until after this beginning stage that the music gained an audience among middle-class city dwellers. ${ }^{8}$ Monroe's music stood firmly in two worlds: the popular and the traditional. ${ }^{9}$

There are many contradictions at the core of bluegrass. For one, the music exhibits characteristics of a folk tradition but is marketed as a popular music. Another is that despite its folk characteristics, bluegrass is played by virtuosic musicians who are often professionals. It also developed in rural Appalachia but was later taken up by the urban-based folk revival. Finally, it is music played by whites for a white audience but is undeniably influenced by West African traditions.

Ralph Rinzler's liner notes for American Banjo Scruggs Style point to the significance of Anglo-American folk song and argues that bluegrass music is a rediscovery of something that had been forgotten: "The banjo along with many of the 'old-time' songs have been revived and numerous bluegrass bands, patterned on those of Scruggs and Monroe, were [performing] and making recordings for well-known companies." ${ }^{10}$ Writing in Esquire, Alan Lomax described bluegrass as "...the first true orchestral form in five hundred [in truth, three hundred plus] years of Anglo-American music, and their silvery, pinging sound [provided] a suitable, yet modern and 'hot,' setting for the songs of the frontier with which America [has] recently fell in love."'11

\footnotetext{
${ }^{8}$ Rosenberg, 6 .

${ }^{9}$ Crawford, 742 .

${ }^{10}$ Ibid., 744.

${ }^{11}$ Crawford., 744.
} 
Both Rinzler and Lomax acknowledge one type of Anglo-American folk music, old-time Appalachian music, as a direct antecedent to bluegrass. Other writers, however, point to another influence: music that is descended from West African traditions. Robert Cantwell, for example, writes: "Bluegrass echoes blues and ragtime, jazz and swing, and of course old-time mountain and hillbilly music." ${ }^{12}$ Cantwell went on to describe bluegrass as an updated form of the old mountain dance band but points out that it can just as easily be dubbed, "white blues," if we focus on subject matter, "country jazz," if we consider its execution. ${ }^{13}$

These two distinct cultural influences are apparent when we examine the characteristics of the bluegrass sound. As Cantwell writes:

These songs, even when they are originally composed by the musicians themselves, remind us strongly of hillbilly music [old-time Appalachian folk music], for bluegrass repertoire, like the hillbilly, is rooted in the Anglo-American folk tradition and has borrowed many songs congenial to that tradition from nineteenth-century middle-class parlor or sentimental songs as well as Negro traditions. ${ }^{14}$

\section{The Five Characteristics of Bluegrass}

Perhaps the most extensive description of bluegrass music is Mayne Smith's

"Introduction to Bluegrass," published in 1965. According to Smith, “...bluegrass is a style of concert hillbilly [country] music performed by a highly integrated ensemble of voices and nonelectrified ensemble of instruments, including a banjo played in Scruggs-style."15

Smith goes on to identify five musical and extra-musical characteristics of bluegrass:

\footnotetext{
${ }^{12}$ Robert Cantwell, Bluegrass Breakdown: The Making of the Old Southern Sound (Chicago: University of Illinois Press, 2003), 60.

${ }^{13} \mathrm{Ibid}$.

${ }^{14}$ Cantwell, 67.

${ }^{15}$ Mayne L. Smith, “An Introduction to Bluegrass.” Journal of American Folklore. 78, no. 309 (Jul. - Sep. 1965), 246.
} 
1. It is played by professional, white, Southern musicians, mostly for a white, Southern audience. It is based in the musical traditions of the South.

2. Unlike other hillbilly styles, bluegrass is not dance music.

3. Bands consist of four to seven males who sing in as many as four parts and play acoustic instruments.

4. The roles of vocals and instruments are formalized in a bluegrass group, much like a jazz band. Instruments serve one of three roles and change roles according to predictable patterns.

5. Bluegrass is the only full-fledged string band style in which the banjo has a major solo role, emphasizing melody over rhythm. The distinct bluegrass banjo style was developed by Earl Scruggs (1924-2012), one of Monroe's Blue Grass Boys, in 1945. Every bluegrass band has a banjo player who imitates Scruggs's original style. ${ }^{16}$

Obviously, some parts of Smith's definition are now quite dated. Bluegrass stars like Allison Krauss, a female fiddle player and vocalist, and Tony Trischka, a banjo player from upstate New York, defy Smith's statement that the style is played by Southern, male musicians. Even at the time Smith wrote the article, bluegrass was not restricted to the professional musician. There were just as many amateur bluegrass groups in the 1960s as there are now. Smith may have included this in his definition in order to differentiate bluegrass from other styles, such as old-time music (discussed in the next chapter) which is played mostly by non-professionals. Despite all of this, Smith's article was the earliest definition of the style, and remains the most extensive, and for that reason any exploration of bluegrass should begin here.

\footnotetext{
${ }^{16}$ Ibid., 245.
} 


\section{Instrumentation}

Smith writes that bluegrass bands consist of various combinations of six instruments. The first five are the five-string banjo, mandolin, guitar with steel strings, fiddle, and string bass. The dobro is also used, though some reject it as a true bluegrass instrument since there was no dobro in Monroe's original band. The guitar and banjo are the two instruments most critical to the style but at least one of the others must be added to form a complete band, and most bands have four or more players.

Other instruments such as drums, electric guitars, autoharp, mouth harmonica, Jew's harp, accordion, and electric organ are occasionally added to groups. These extra instruments are rare on the concert stage and instead most often appear on recordings. This suggests that additions of this kind are the idea of recording companies and many musicians and fans disapprove of these departures. In any case, the extra instruments are not integrated into the ensemble in the same way as the standard instruments. ${ }^{17}$

Neil Rosenberg suggested that the purely acoustic nature of bluegrass is most likely a historical accident. Most early bluegrass musicians grew up without electricity in their homes and thus played acoustic instruments out of necessity. During the Grand Ole Opry days, the use of electric instruments was discouraged by the conservative representatives of the country music industry, such as George D. Hay (the founder of the Grand Ole Opry). At that time, bluegrass was not the only purely acoustic style of country music but by the late fifties and early sixties this feature became a defining characteristic. The proponents of the so called "folk-boom" considered electric instruments to be an exemplar of mass culture and thus inauthentic. As

\footnotetext{
${ }^{17}$ Smith, 246.
} 
bluegrass gained its new audience through the boom, the use of acoustic instruments became, "a philosophical position." 18

Smith mentioned the unique role of the five-string banjo in bluegrass and emphasized that the Scruggs style of playing the instrument is inextricably linked to bluegrass. In other words, Scruggs's three-finger picking technique always reminds one of bluegrass, and it is extremely rare for a bluegrass band to have a banjo player who plays with any other technique. ${ }^{19}$

This "up-picking ${ }^{20 "}$ style with metal picks allowed Scruggs to play a perpetual sequence of loud, powerful notes that contributed to the musical texture that would forever be linked to bluegrass. He also refused to, "take up the role of comedian that banjo players often filled in country music ensembles." ${ }^{21}$ Thanks to his virtuosity and on-stage personality, bluegrass banjo solos are often the most musically complex and exciting. Scruggs's style was emulated by other five-string banjo players, one of the earliest being Ralph Stanley in the late 1940s. ${ }^{22}$

\section{Vocal Style}

The vocal style of bluegrass is highly stylized and impersonal in the tradition of AngloAmerican folk singing. As with Monroe's original group, bluegrass singing is higher in register than other kinds of country music. The clear and cutting tone of the voices was described as "the high lonesome sound" in the $1960 \mathrm{~s} .{ }^{23}$ The often tense sounding lines sometimes reach up to an octave above middle $\mathrm{C}$. Bluegrass songs are played in keys which allow the voices to sing as

\footnotetext{
${ }^{18}$ Neil V. Rosenberg. Bluegrass: A History. (Chicago: University of Illinois Press, 1985) 6.

${ }^{19}$ Smith, 245.

20 "Up-picking," used in Scruggs-style refers to plucking the strings from the bottom up with picks or the finger tips. This is distinctly different than the technique used in clawhammer or frailing styles which involve stroking the string from the top down, usually with the back of the fingernails.

${ }^{21}$ Crawford, 743.

${ }^{22}$ Ibid., 743.

${ }^{23}$ Rosenberg, 7.
} 
high as possible. High notes are sung in falsetto and vibrato is rare. The best bluegrass singers sing in a loud, almost shouting tone. Held pitches are often slightly flatted, and vocal lines are ornamented with rising attacks, falling releases, and grace notes. ${ }^{24}$

Singing in unison is extremely rare ${ }^{25}$ and in fact vocal harmony in two, three, and four parts is one of the most prominent aspects of bluegrass music. These parts are referred to as the "lead," "tenor," "third" (or "high tenor" or "baritone" depending on where they are voiced), and "bass." Vocal arrangements are so conventionalized that a talented singer is easily able to add his part to songs that he has not previously heard. ${ }^{26}$

\section{Ensemble Interaction}

There are three roles that instruments and voices assume in a bluegrass ensemble. A lead part carries the main melodic line and is played by an instrument or sung. There is a backing part which contrasts with and supports the lead but never overpowers it. The third role provides a consistent rhythmic and harmonic structure. Each instrument is capable of filling any of these three roles at any given time but most of the time they emphasize only one or two. The fiddle, banjo, and dobro usually fill either the lead role or the back-up role. The mandolin also plays the lead but also the percussive rhythmic role when not doing that. The guitar and bass almost always provide the rhythmic structure. The guitar also plays the backing role by playing short melodic runs and rarely plays a lead line. ${ }^{27}$

\footnotetext{
${ }^{24}$ Smith, 247.

${ }^{25}$ Rosenberg, 7.

${ }^{26}$ Smith, 247-248.

${ }^{27}$ Smith, 246-247.
} 
All of this serves to create the impression of "multiple parts in continual interaction.",28

As an example, Smith describes various combinations of instruments and explains how they would interact in a bluegrass band:

Except when four voices are singing lead, the fiddle and banjo in a standard band usually play complex backing patterns while the guitar, bass, and mandolin maintain the rhythm; these functions are preserved when fiddle or banjo has the lead. When the mandolin is leading, the banjo tends toward a less melodic, more rhythmic function to compensate for the lack of mandolin rhythm. Without a mandolin to accent the up-beats, the banjo usually assumes a strong rhythmic role unless the band uses a dobro or second guitar to add to the background. Conversely, bands that include a dobro tend to understress or eliminate the role of one of the other lead instruments. On slower songs this may be the banjo; on fast songs, it is likely to be the mandolin. When the dobro plays lead, other instrumentalists simplify their music, since the dobro is relatively quiet and does not stand out clearly against a complex background. Sometimes lead instruments play duets; most common are double banjos or fiddles, and fiddle-banjo duos. ${ }^{29}$

\section{Musical Characteristics}

Melodically, bluegrass songs are anchored in the Anglo-American tradition. Melodies are based on what is commonly referred to as a gapped pentatonic scale or the diatonic scale. They also exhibit African-American melodic traits such as neutral (intervals that are neither major nor minor, also called "blue notes") thirds, fifths, and sevenths. Harmonically, bluegrass tunes rely on the three primary triads of a major key: I, IV, and V. The relative minor (vi) is the most common minor triad used. The triad built on the lowered seventh scale degree is used support melodies that are based on the gapped pentatonic scale. The most common chord progressions are: I, IV, I, V, I; I, III, IV; and I, VI, II, V. ${ }^{30}$

Two meters are used in bluegrass and vary according to the type of song. Ballads and religious songs are most often in triple meter, notated best as 3/4. Other songs are in

\footnotetext{
${ }^{28}$ Ibid, 247.

${ }^{29}$ Ibid.

${ }^{30}$ Ibid., 248.
} 
duple meter, which could be notated as $4 / 4$ or $2 / 4$ depending on the tempo rather than on stress patterns. Triple meter songs are usually at a moderate tempo about 115 beats per minute or fast at $190 \mathrm{bpm}$. Duple meter songs tend to proceed at around $160 \mathrm{bpm}, 250$ bpm or $330 \mathrm{bpm}^{31}$

The speed of bluegrass music as a whole is faster than any other country style. The impression of speed is enhanced by accented upbeats, off-beat melodic phrasing, and changes in pitch to accent the rhythm. Even at incredibly fast tempos, banjo players play a steady stream of sixteenth notes (four notes for every quarter note the bass plays) which contributes to the sense of speed. Some bands, including Bill Monroe's, may subtly alter the tempo throughout the song. They tend to speed up at the beginning of phrases to create a surging effect. ${ }^{32}$

Certain rhythmic devices are used at the end of bluegrass songs. Slow songs end with a few measures of rubato and almost all fast songs end with the "shave and a haircut" rhythmic and melodic cliché. ${ }^{33}$ The feeling of "punch" or "drive" is highly valued. These terms refer to the rhythmic tension that exists between the guitar and bass, which emphasize the first and third beats, and the lead instruments which play the melody and often emphasize two and four. ${ }^{34}$

Bluegrass songs are almost always strophic in form. They divide into one or two large melodic units, each consisting of two or four phrases repeated in sequence to complete an entire piece of music. Vocalists and instrumental soloists take turns playing the melody or some variation on it. This usually results in eight repetitions of the full two part sequence. ${ }^{35}$

\footnotetext{
${ }^{31}$ Ibid.

${ }^{32}$ Ibid.

${ }^{33}$ Ibid., 248-249.

${ }^{34}$ Rosenberg, 7-8.

${ }^{35}$ Smith, 249.
} 


\section{Repertoire}

The subject matter of bluegrass songs is similar to the content of Anglo-American folksong: Christian-based religious experience, love, and death. In religious songs, life is depicted as a time of misery and death and considered only a passage to a better place. Secular songs may express sorrow or anger over the loss of a lover or possibly nostalgia for a home place or one's parents. Sometimes religious themes mingle with nostalgic themes. The few joyous bluegrass songs reference religious experience or the memories of being back home. The most common subject of ballads is death, particularly violent death, in which one lover kills another, or his rival, or himself upon rejection. The punishment for these crimes, such as execution or lifetime imprisonment, is also a common theme. Texts determine the identity of songs, as a large number of songs share tunes. At the same time, the poetic and literary merits of texts seem to matter little to bluegrass musicians. The only distinction they make between songs is whether they are sacred or secular, serious or comic. ${ }^{36}$

The sources of the bluegrass repertoire vary greatly. A fifth of bluegrass pieces are borrowed directly from the Anglo-American folk tradition. These include instrumental tunes, lyric songs, and ballads, which are derived from the English broadside tradition. AfricanAmerican songs are slightly represented by a few specific borrowings. Other songs are originally composed by bluegrass musicians and are often adopted from traditional tunes and words. Some come from other country styles and others come from nineteenth century parlor songs. ${ }^{37}$ Purely instrumental music is also part of band's repertoire and is a vehicle for demonstrating the musician's virtuosity. ${ }^{38}$

\footnotetext{
${ }^{36}$ Ibid.

${ }^{37}$ Ibid, 250.

${ }^{38}$ Rosenberg, 8 .
} 


\section{The Influence of Traditions: American, European, and African}

Bluegrass shares more stylistic traits with American folk traditions than any other form of contemporary country music. Melodies, harmonic accompaniment, and phrase structure follow patterns found in Anglo- and African-American traditions. Vocal style is akin to traditional ballad and psalm singing and singing in parts is derived from the shape-note tradition and black gospel styles. The style also exhibits the melodic characteristics and structure of the blues.

The rhythmic stress on the upbeat, improvised solos, and the general idea of ensemble integration are based on West African musical practices. Smith contended that these elements came to bluegrass through northern popular music and jazz with western swing as a possible intermediary. Western swing is a style of country music that originated in Texas in the 1920s and later flourished in the 1940s. The early guitar and fiddle bands that played this style borrowed freely from the jazz bands of the era. Bands like Bob Wills's Texas Playboys hired jazz-oriented musicians and by the 1930s added electrified guitars and drums and came to sound very similar to swing bands. ${ }^{39}$

The commercial and popular nature of the style is evident when one considers its extramusical characteristics. The music was developed, defined, and later changed by professional musicians. It requires a degree of virtuosity and a type of ensemble playing, “...seldom found among folk musicians in the United States. ${ }^{40}$ Bluegrass musicians play in professional venues, such as medicine shows, concerts, radio programs, and recording sessions. A repertoire that

\footnotetext{
${ }^{39}$ Bill C. Malone. "Western Swing." In Grove Music Online. Oxford Music Online, http://www.oxfordmusiconline.com/subscriber/article/grove/music/30173 (accessed September 23, 2012).

${ }^{40}$ Smith, 250.
} 
includes religious songs, an emphasis on showman-like arrangements, and a tendency towards incredibly fast tempos, differentiate bluegrass bands from amateur rural ensembles. ${ }^{41}$

At the same time, bluegrass is closely related to the folk tradition on an extra-musical level. First, music is almost always learned orally and rarely through notation. Songs are learned by listening to radio broadcasts, disc recordings, and from other musicians. Second, bluegrass musicians are in constant contact with the folk tradition. Ninety percent are from the South, and eighty percent are from Appalachia. Professional performers connect to rural audiences through the radio, recordings, and personal appearances, and amateur bands are found in communities in which folk tradition is a part of the community. ${ }^{42}$

It is perhaps right then to view bluegrass not as a folk style, or as a popular music, but, as Robert Cantwell suggested, a modern representation of Appalachian traditional music which has been adapted for the concert stage. ${ }^{43}$ It is a vehicle for preserving the characteristics of that folk tradition. Monroe's fiddle tune Land of Lincoln, for example, was not based on a specific traditional song but, according to Monroe himself, was written to “...go the way I thought Abraham Lincoln might have heard it—a tune like he might have heard when he was a boy from some old-time fiddler., ${ }^{44}$

The relationship goes beyond such mythic ideas. The lyrical content, ethos, instrumentation, and vocal style all relate to traditional Anglo-American music. Anglo-American

\footnotetext{
${ }^{41}$ Ibid.

${ }^{42}$ Ibid., 251.

${ }^{43}$ Robert Cantwell, Bluegrass Breakdown: The Making of the Old Southern Sound, (Urbana, Illinois: University of Illinois Press, 1984), 71.

${ }^{44}$ Alice Foster, "My Life in Bluegrass: An Interview with Bill Monroe, Newport Festival Program (1969), 16, quoted in Cantwell, 34.
} 
folk singing for instance had a great influence on Monroe's own style, and it can be traced back to a number of folk practices such as black field hollers and Primitive Baptist Hymnody. ${ }^{45}$

The relationship to West African musical traditions is less obvious but exists nonetheless. Bluegrass music would not be the same without it. The banjo, for example, is African in origin. Bluegrass tunes follow a jazz-like format with alternating solos over a predictable and consistent pattern of rhythmic and harmonic structure. This formal characteristic is essential to its execution and performance and allows a group of bluegrass musicians who are unacquainted to easily play through tunes in a jam session environment. As it does in jazz, this format creates a backdrop for soloing musicians to demonstrate their virtuosity and individuality. ${ }^{46}$ The music also has what Crawford called a "black-inspired rhythmic drive."

Bluegrass, like almost all American vernacular music, is the result of the long-term, consistent first-hand contact between European and West African musical cultures. As Cantwell puts it:

"Like jazz, bluegrass is the fruit of a union of Afro-American musical ideas with the European, especially the Celtic, on the folk and popular levels, and its roots are to be found in the popular culture of the nineteenth and early twentieth century America, in blackface minstrelsy in particular, transformed by its sojourn in Appalachian folklife."48

Through this process of acculturation, bluegrass emerged as a new and uniquely American music that exhibited the musical and extra-musical characteristics of the distinct cultures that produced it. It is also important to understand when and where these cultural exchanges took place. The next chapters attempt to document these interactions while recounting the history of bluegrass music. The history of the development of bluegrass music from its roots in the Appalachian mountain region to its emergence in the

\footnotetext{
${ }^{45}$ Crawford, 742 .

${ }^{46}$ Rosenberg, 6-9.

${ }^{47}$ Crawford, 742.

${ }^{48}$ Cantwell, xix.
} 
1940s is covered first. Next the geography, the musical culture, and the nature of contact between African and European groups in the Appalachian mountain region are examined. Finally, the history of the instruments of bluegrass instruments as well as their playing styles is explored. 


\section{CHAPTER 2}

\section{THE PREHISTORY OF BLUEGRASS MUSIC}

\section{Acculturation and Bluegrass}

According to Allen Farmelo, there are two traditional histories of bluegrass music. The first history focuses solely on the life and accomplishments of Bill Monroe. There is no mention of the diverse history of the music that led to bluegrass except the old-time music that Monroe played before the 1940s. This history ignores the importance of the many musical developments that preceded bluegrass as well as Monroe's place in a larger historical narrative.

The second traditional history of bluegrass begins as far back as the early 1600 s in the Jamestown colony. This version acknowledges the musical contributions of the British, Scottish, Irish, and even the poetry of the ancient Greeks to American music and to bluegrass. It also recounts how the early British settlers gradually moved into the Carolinas, Tennessee, Kentucky, and the rest of Virginia and created traditional Appalachian folk music by the $1800 \mathrm{~s}$. After the development of the phonograph and the radio in the twentieth century, the music, now known as country music, spread to people all over the United States by way of musical acts such as the Monroe Brothers. It goes on to say that one of the brothers, Bill, formed his own band in the 1930s and that this was the beginning of bluegrass music.

What both histories ignore, according to Farmelo, are the contributions of AfricanAmerican musicians to country music and the influence of their musical traditions on bluegrass. European contributions to bluegrass music are the focus of these histories despite substantial 
evidence that black musicians had just as much influence on the development of bluegrass. As Farmelo put it, 'Bill Monroe never played music with 'the Greeks,' though he repeatedly told interviewers that, for at least one memorable and formative night during his teens, he played for dancers with black bluesman Arnold Schultz ${ }^{49}$ [sic] until sun up., 50

Arnold Shultz's influence on Monroe is one of the many examples of the exchange of musical ideas that occurred between blacks and whites throughout the history of American music. It also proves that Monroe had direct contact with the blues and the black musicians that played it. In the same interview, Monroe stated plainly that his own musical style owes a great deal to Shultz and the blues. ${ }^{51}$ Bluegrass music would not be the same and would probably not exist if Monroe never met Shultz.

Although primarily associated with southern whites, bluegrass, like virtually all American music, is actually the result of a blending of European and non-European cultures including West African musical traditions. Bluegrass, like virtually all popular music in the United States, did not develop from a single strain of influence or from a homogeneous group of people. Instead it was the result of a complex multicultural fusion. That interaction has been obscured by notions of cultural segregation. ${ }^{52}$ The history of bluegrass begins long before Monroe and his Blue Grass boys took the stage at the Grand Ole Opry, long before the Monroe brothers were playing old-time Appalachian music, even before Monroe met Arnold Shultz. The true roots of bluegrass music lie almost three hundred years before all of that when Europeans

\footnotetext{
${ }^{49}$ Arnold Shultz's family name is often misspelled.

${ }^{50}$ Allen Farmelo, "Another History of Bluegrass: The Segregation of American Popular Music, 1820-1900," Popular Music And Society 25, no. 1-2 (March 1, 2001): 180-182.

${ }^{51}$ James Rooney, "Bossman Bill Monroe," in The Bluegrass Reader, ed. Thomas Goldsmith (Chicago: University of Illinois Press, 2004): 37.

${ }^{52}$ Farmelo., 180.
} 
and Africans, brought together by the slave trade, were first exposed to each other's distinct musical cultures.

West African music was brought to the New World by the second half of the seventeenth century, and while there are virtually no accounts that reveal the nature of African music in mainland America at the time, we can look to sources written in the West Indies for a picture of the early stages of acculturation. These records show that African music, though changed by contact with Europeans, maintained its distinctive elements in the New World for over one hundred and fifty years. These distinctly West African elements include dance steps, derisive or satiric singing, call-and-response form, and bodily movement and hand clapping to accentuate rhythms. Around 1800, these practices began to be widely observed on as the mainland as well. African instruments, such as rhythm sticks, the banjo, musical bow, quills or panpipes, and balafo, were also brought over on the earliest slave ships, and a few accounts of their existence in the American colonies have been found. The ancestors of the banjo were observed as early as 1678 in the West Indies and mentioned often by writers in the seventeenth and eighteenth centuries. It is clear from these reports that Europeans considered the instrument to be African in origin.

The earliest reports of acculturation come from these sources as well. There are numerous accounts of native Africans performing European dances and playing European instruments in the West Indies during the seventeenth century. The first records of blacks playing white instruments and white music on the mainland United States date from the beginning of the 
nineteenth century. These accounts tell of slave musicians playing at Christmas celebrations in South Carolina and at a Mardi Gras celebration in 1808 in New Orleans, Louisiana. ${ }^{53}$

\section{Black and White Cultural Exchange in the South and in Appalachia}

Country music evolved from the folksongs, ballads, dances, and instrumental pieces brought to North America by Anglo-Celtic immigrants. Taking on influences from other sources, mainly African Americans, it eventually became a musical style "strong enough to survive, and even thrive, in an urban-industrial society. ${ }^{, 54}$ Though this British folk music came to all Englishspeaking North America, it was only in the southern United States that British folk music developed into a commercially viable musical product in the twentieth century.

The unique mixture of geography, economics, religion, and politics of the American South bred a social conservatism that encouraged the preservation of older values and institutions. The agrarian society of the region was isolated from the rest of the nation. In the years leading up to the Civil War, as the North became urbanized and industrialized, the South clung to its old ways, which included slavery-dependent farming, a stringent racial hierarchy, and evangelical Protestantism. The result of this adamant resistance to change was a unique Southern folk culture. ${ }^{55}$

Interaction between poor whites and black slaves in the South was critical to the development of country music, and despite popular belief, these interactions were actually relatively commonplace. The stereotype of a musically segregated South emerged after the Civil

\footnotetext{
${ }^{53}$ Dena J. Epstein, Sinful Tunes and Spirituals: Black Folk Music to the Civil War (Urbana and Chicago: University of Illinois Press, 2003), 343-345.

${ }_{55}^{54}$ Bill C. Malone, Country Music U.S.A. (Austin, TX: University of Texas Press, 1985 rev., 2002), 1.

${ }^{55}$ Ibid., 1-3.
} 
War, and with it came the assumption black and white musical cultures were not related.

However, though segregation was a very real aspect of southern life, its effects were never absolute. Some sociologists, historians, and folklorists now contend that for poor whites, class distinctions often had more influence than racial ones. There is evidence that blacks and whites of the same economic class interacted less as members of separate racial groups and more as members of the same group, collectively looked upon as lower in status by the planter class. Because of these interactions, the earliest music in the United States might be best understood as a musical culture shared among blacks and whites.

This group of poor whites consisted of tenant farmers who did not own land or slaves and were often indebted to the elite land-owners and thus legally obligated to work for them without pay. The skin color of these whites ensured little or no privilege in society. And though racism was not totally absent among them, this group often formed connections with black slaves, who were essentially of the same economic class. ${ }^{56}$

Blacks and whites in the South also shared a common religion. The church was a place of interaction between poor whites and black slaves, and church services often led to blacks and whites making music together. Religious conversion of Africans by whites was an early catalyst for acculturation in the New World. It was a precondition for the development of the Negro spiritual and led to some of the earliest direct contact between black and white music. ${ }^{57}$ In the early 1800 s, the massive outdoor camp meetings of the Great Revival, also called the Second Awakening, would often start as separate black and white gatherings that would eventually

\footnotetext{
${ }^{56}$ Farmelo, 182-183.

${ }^{57}$ Epstein, 100-111.
} 
merge into each other. This interaction would set the stage for shared black and white religious music making. ${ }^{58}$

Blacks and poor whites lived close to each other in many places throughout the South. This geographical proximity encouraged musical interaction between the two groups. Cecelia Conway examined one such region which lies in the mountains on the border of Virginia, North Carolina, and Tennessee. This area, which Conway identified as Sugar Grove, was significant because it has a well documented history of black and white musical interaction, particularly involving the banjo. ${ }^{59}$ Blacks and whites had similar social relationships in other places in the Southeast, and Farmelo concluded that the same kind of musical exchanges happening in Sugar Grove were occurring elsewhere. ${ }^{60}$

The Appalachian Mountains and the foothills that surround them have their own geographical, economical, and social characteristics that set them apart from the rest of the Southeastern United States. Even though the father of bluegrass Bill Monroe was not from Appalachia, the people who lived in these highland areas were crucial players in the development of early country music and bluegrass. Artists such as Jimmie Rodgers and the Carter Family recorded the first hillbilly records in Bristol, Tennessee, in the heart of Appalachia. Later Bill Monroe became popular among the people who lived in the mountains. The mountains were also the cradle for the mountain string band, the precursor to the bluegrass ensemble. And, as folk music collectors Cecil Sharp and Olive Dame Campbell discovered, the area was a bastion of British folk music in the United States.

\footnotetext{
${ }^{58}$ Farmelo, 184-185.

${ }^{59}$ Cecelia Conway. African Banjo Echoes in Appalachia. (Knoxville: The University of Tennessee Press, 1995): 139-146.

${ }^{60}$ Farmelo, 187-190.
} 
Bluegrass music appealed to the people of Appalachia because it sounded familiar and evoked a certain sentimentality that other forms of country music in the 1940 s did not. When Monroe came to the Grand Ole Opry in 1939, most country music fans were listening to artists such as Ernest Tubb, Bob Wills, Gene Autry, and Roy Acuff, all of whom were characterized by a western motif. Mountain music had become antique. Monroe took this old form and added elements from other musical styles to create his sound. His music was traditional Appalachian music transformed out of necessity for the concert stage. Cantwell called it, "a representation of traditional Appalachian music in its social or assembly form..." ${ }^{\text {61 }}$ The original social context for this music was that of square dances and house parties, not the stage or the recording studio. Bill Monroe adapted this music for these new professional settings, and when listeners from Appalachia heard bluegrass over the radio or on a record, they no doubt heard the familiar sound of the square dance band or a string band playing for a party at the home place. ${ }^{62}$

The national popularity of bluegrass waned after the mid-twentieth century. The music is well-known today because it was discovered by people such as Alan Lomax and Ralph Rinzler who saw it as a new musical form with roots in Appalachian folk music and not as a subset of commercial country music. These new fans were mostly young, urban intellectuals who considered bluegrass to be an authentic form of expression that stood in contrast to other popular music of the time. Through them, bluegrass became a part of the folk revival of the 1950s and 60s. The music represented the people of Appalachia, who the revivalists saw as poor, working class whites from a simpler and more cohesive culture. ${ }^{63}$

\footnotetext{
${ }^{61}$ Cantwell, 71.

${ }^{62}$ Ibid.

${ }^{63}$ Rosenberg, 13.
} 
The idea of a separate Appalachian culture did not originate with Lomax and Rinzler but had been at least half a century in the making. According to Farmelo, by 1900 several social discourses appeared that define a separate and unique group of whites: the hillbillies. The authors of these works asserted that the hillbilly culture developed in geographical and economic isolation and without influence from outside groups. Through marketing and advertisement campaigns the music industry perpetuated this hillbilly stereotype and solidified the distinction between the music of poor rural whites and that of other groups. White records were aimed at white markets and black records were aimed at black markets. These broad and imprecise labels served to obscure the reality of the social and racial complexity that led to the development of country music and later bluegrass music. ${ }^{64}$

In reality though, African Americans have always had a strong presence in Southern Appalachia. The presence of blacks in the region has either been ignored or explicitly denied by politicians, historians, and scholars since the middle of the nineteenth century. When ballad collectors such as Francis James Child, John Harrington Cox, and Cecil Sharp went to Appalachia they focused exclusively on documenting the remnants of white folk music. In their writings about the region, Sharp, and others such as Arthur Kyle Davis and Cratis Williams, emphasized the moral and cultural purity of the region as well as the racial homogeneity of the mountain folk. ${ }^{65}$ Modern research though, such as the studies done by William H. Turner ${ }^{66}$ and Wilma A. Dunaway, ${ }^{67}$ has revealed that many more African Americans (as well as whites of

\footnotetext{
${ }^{64}$ Farmelo, 196.

${ }^{65}$ Fred J. Hay, "Black Musicians in Appalachia: An Introduction to Affrilachian Music," Black Music Research Journal, 23, no. 1/2 (Spring - Autumn, 2003): 1-6.

${ }^{66}$ William H. Turner, "The Demography of Black Appalachia: Past and Present," in Blacks in Appalachia, ed. William H. Turner and Edward J. Cabbell (Lexington: University of Kentucky Press, 1985) ref. in Hay.

${ }^{67}$ Wilma A. Dunaway, Slavery in the American Mountain South. (New York: Cambridge University, 2003), ref. in Hay.
} 
non-Anglo decent) lived in the Appalachian mountain region than was previously thought. The music of the region reflects this diversity. ${ }^{68}$

Bill C. Malone insists that the cultural interchange that created country music happened just as easily between blacks and whites in the mountains as it did in the flatlands regions of the Southeast. Before the 1920s, there were accounts of black musicians being seen and heard by whites on street corners and in works camps. Early hillbilly singers such as Dock Boggs, Frank Hutchison, and Dick Justice performed songs and styles they had learned from black musicians. $^{69}$

Fred J. Hay notes that the influence of black musicians on whites in Appalachia was profound but is now rarely acknowledged. In the early twentieth century, people in the mountains were listening to blues records and to black guitarists such as Blind Lemon Jefferson and Blind Blake, blues singers such as Bessie Smith, and to the jazzy string band music of groups such as the Mississippi Sheiks. The guitar itself was introduced to the region by blacks. ${ }^{70}$

It was this interaction between blacks and whites in the unique social, economical, and geographical environment of the Southeast and particularly in Appalachia that led to the development of commercial country music and later bluegrass. However, country music and bluegrass did not appear spontaneously. There were many developments that preceded their emergence and each was the result of the blending of black and white musical ideas. And while not every one of these developments occurred in southern Appalachia, they nonetheless had a profound impact on the music that developed there.

\footnotetext{
${ }^{68}$ Hay, $1-7$.

${ }^{69}$ Malone, 4-5.

${ }^{70}$ Hay, 7 .
} 


\section{The History of Old-time Music}

Contemporary residents of Appalachia refer to the earliest mountain music as "old-time" music. The term is used to identify a variety of traditional musical genres found in the region, including: ballads and folk songs; instrumental music such as fiddle and banjo tunes; traditional sacred songs; popular songs recorded in the late 1920s and 1930s that entered the mountain tradition by way of records and the radio; commercial country music prior to World War II, such as the music of the Carter Family and the Monroe Brothers; and the blues, brought to Appalachia by blacks. ${ }^{71}$

One of the most important early developments in old-time music occurred before the founding of the United States: the coming together of the European fiddle and the African banjo. The ensemble formed by these two instruments directly preceded the mountain string band, which in turn led to the bluegrass ensemble. Most importantly though, the human interaction involving these two instruments set the stage for a great deal of cross-cultural musical exchange between blacks and whites in Appalachia.

The Fiddle and the Banjo in the Mountains

The fiddle came to North America in the hands of the original European settlers and even now has a place in nearly every folk tradition on the continent. ${ }^{72}$ In the American colonies the fiddle was primarily used to accompany dances. It was also very popular among amateurs, a

\footnotetext{
${ }^{71}$ David A. Brose, "Old-time Music," in Encyclopedia of Appalachia Online accessed 2 Apr 2013, $<$ http://www.encyclopediaofappalachia.com/entry.php?rec=162>

${ }^{72}$ Malone, 17.
} 
notable example being Thomas Jefferson, and professional musicians. The instrument was also played by slaves and indentured servants. ${ }^{73}$

In the South the fiddle appeared at social and political events and at rural house parties. Though most of the fiddlers hired to play these parties were farmers by trade, they helped to lay the foundations of professionalism in country music. Fiddlers would also play at fairs, medicine shows, and circuses, and they would compete in fiddle contests. These competitions have been a source of income for musicians for centuries, and the earliest documented contest was in Hanover County, Virginia in $1736 .^{74}$

The instrument was brought to Appalachia by the earliest explorers and settlers. In Pennsylvania, Scottish and Irish immigrants arrived in large numbers in the eighteenth century, and they brought their fiddles with them. ${ }^{75}$ In southern and central Appalachia the Scots-Irish established a repertory of songs, breakdowns, and reels descended from old-world genres like jigs, hornpipes, and ballads. African melodic characteristics, playing style, as well as black banjo music also influenced mountain fiddle playing and resulted in a highly syncopated type of fiddle dance music unique to Appalachia. ${ }^{76}$ This dance music laid the foundations of Southern folk fiddling and persisted in later styles such as country and bluegrass. ${ }^{77}$

Some of the earliest exchanges of musical ideas between whites and blacks occurred through fiddle playing which, “...provided one of the earliest, most long lasting, and most deeply influential musical and cultural meeting points between African and European peoples.”,78

\footnotetext{
${ }^{73}$ Jeff Todd Titon, "Fiddle" in Encyclopedia of Appalachia Online, accessed. 1 Apr 2013, $\mathrm{http}: / / \mathrm{www} \cdot$ encyclopediaofappalachia.com/entry.php?rec $=80$

${ }^{74}$ Malone, 17-18.

${ }^{75}$ Conway, "Black Banjo Songsters in Appalachia," 151-152.

${ }^{76}$ Titon.

${ }^{77}$ Paul F. Wells, "Fiddling as an Avenue of Black-White Musical Interchange,." Black Music Research Journal, 23, no.1/2 (Spring - Autumn, 2003): 142.

${ }^{78}$ Wells, 145.
} 
Slaves were playing the fiddle as early as the 1690 s, and they were playing the popular white dance tunes of the day ${ }^{79}$ There are numerous contemporary references to blacks playing the fiddle in the colonial era and into the late nineteenth century. In the first half of the twentieth century, southern black fiddlers remained an influential but overlooked presence. There are even a few recordings of blacks such as Jim Booker, Andrew Baxter, and Eddie Anthony playing traditional fiddle tunes. Current scholarship and research has revealed that the black fiddle tradition still exists in a few isolated pockets of the South. ${ }^{80}$

The banjo is the first distinctly African-American instrument and developed in North America as part of a resilient West African heritage. ${ }^{81}$ It evolved from earlier instruments brought from Africa by slaves. These predecessors were referred to by a variety of names including "banjar," "bandore," and "banza," and they all had a basic design: a pole attached to a gourd that was strung with four strings. Later versions of this early instrument included a flat fingerboard and tuning pegs that allowed for easier bending of and sliding between pitches. The banjar was seen in Maryland and Virginia as early as 1740 and black banjar players were noted in the Appalachian frontier in 1800 (Knoxville, Kentucky) and 1806 (Wheeling, Virginia). ${ }^{82}$ The banjar and the traditional down-stroke playing style were brought to Appalachia by enslaved Africans,${ }^{83}$ and by 1830 musicians of Scotch-Irish heritage began to play these gourd instruments in a similar fashion.. ${ }^{84}$

The cultural exchanges between black and whites involving the instrument began on the eastern costal plain and moved along the waterways into the Piedmont and then eventually into

\footnotetext{
${ }^{79}$ Epstein, 80.

${ }^{80}$ Wells, 136.

${ }^{81}$ Farmelo, 189.

${ }^{82}$ Cecelia Conway, "Banjo" in Encyclopedia of Appalachia Online, accessed 1 Apr 2013, $<$ http://www.encyclopediaofappalachia.com/entry.php?rec=32>

${ }^{83}$ Conway, "Black Banjo Songsters of Appalachia," 150.

${ }^{84}$ Conway, "Banjo."
} 
Appalachia. In 1774 two young white boys at a plantation on the James River were noted interacting with several African musicians. These schoolboys exasperated their tutor Phillip Fithian by playing the banjo (or one of its ancestors) and dancing. ${ }^{85}$ These types of musical exchanges increased in frequency as the upland South was settled and these interactions inspired whites in the mountains to learn the banjo from black mentors.

Outside of Appalachia these black and white mentor relationships helped lay the foundation of minstrelsy, a style of music that emerged in the 1830s and was incredibly popular even into the twentieth century. Thomas Dartmouth Rice was the first to imitate the dancing of slaves on the stage usually to the accompaniment of the fiddle. Joel Walker Sweeney, one of the first known white banjo players also learned his music from enslaved African Americans. The renowned minstrel Dan Emmett learned from a man named Ferguson. One of the earliest white, mountain banjo players, Ferguson learned from blacks in the mountains and passed his knowledge onto white minstrels. ${ }^{86}$

It was this shared interest in the instrument that led to its modern design: five-strings, wooden-rim, and open-backed body. Contrary to traditional narratives, the fifth-string added by Sweeney was not the high G drone string but a fourth melody string. The drone string has an African heritage and is found on the ancestors of the banjo in Africa. Sweeney, one of the earliest minstrels, played a major role in popularizing the instrument in America. His student Dan Whitlock, who played with Dan Emmett and the Virginia Minstrels, went on to popularize the instrument in England and Ireland. ${ }^{87}$

\footnotetext{
${ }^{85}$ Phillip Fithian,. Journal and Letters of Philip Vickers Fithian 1773-1774: A Plantation Tutor of the Old Dominion (Williamsburg, Va.: Colonial Williamsburg). 62, ref. in Conway, "Black Banjo Songsters of Appalachia," 152. ${ }^{86}$ Conway, "Black Banjo Songsters of Appalachia," 152-155.

${ }^{87}$ Conway, "Banjo."
} 
There is some controversy among scholars about how the white residents of Appalachia first learned to play the instrument. The traditional theory is that the instrument was taught to mountaineers by white minstrels sometime in the middle or late nineteenth century. Winans argues that whites in the mountains had little contact with blacks because so few African Americans lived in there. He therefore concluded that whites most likely learned to play the banjo from traveling minstrels. According to him, mountain banjo technique and that of black slaves is only similar because these original banjo techniques were brought from the plantations to the mountains by white minstrels. ${ }^{88}$

Winans's argument, however, rests on two false assumptions: that there was a negligible presence of African Americans in Appalachia and that the black banjo tradition did not exist in the mountains or, at least, was not viable enough for whites to have learned from it. We have already seen that there was, in fact, a strong black presence in Appalachia. Furthermore, Cecelia Conway proved that there was a strong black banjo tradition in the mountains, and that this is where white mountaineers learned the banjo.

In her examination of the black banjo tradition that still exists in Appalachia, Conway found that the surviving pockets of this tradition use the same techniques and tunings as those found in the white banjo techniques. Whites in the mountains also had more frequent and direct contact with black banjo players than they did with the minstrels. Furthermore, by the time the minstrel show came to South, which was not until after 1865, the minstrels were losing interest in the down-stroking banjo technique that became rooted in the mountains. She concluded that black banjo players had more influence on white mountain musicians than minstrels. ${ }^{89}$

\footnotetext{
${ }^{88}$ Robert B. Winans, "The Folk, the Stage, and the Five-String Banjo in the Nineteenth Century," The Journal of American Folklore, 89, no. 354 (Oct. - Dec., 1976): 419.

${ }^{89}$ Conway, African Banjo Echoes in Appalachia, 283-295.
} 


\section{The Mountain String Band}

The combination of the fiddle, an instrument from Europe, and the banjo, an instrument that developed in America from African predecessors, evolved into the mountain string band, a precursor to the bluegrass ensemble. Many different combinations of instruments were common in the South before and after the Civil War. These combinations did not become standardized until the commercialization of early country music. Certain instrument groupings were more successful than others when used for medicine shows, dances and auctions, and one combination that worked particularly well was the banjo and fiddle. ${ }^{90}$

The fiddle and banjo ensemble grew out of slavery; black slave musicians were playing the two instruments together possibly as early as 1774 . Nicholas Creswell wrote an account of a barbeque along the Saint Mary's River near the Georgia-Florida border. The event included performances by a black fiddler and banjo player, but it is not clear if the two instruments were played together. This story does prove though, that the two instruments coexisted at least as early as the eighteenth century. ${ }^{91}$

Conway provided evidence of the combination existing in the Round Peak region of the Blue Ridge Mountains. The history of black and white interchange in this area suggests that the fiddle and banjo have been played together at least since the nineteenth century. ${ }^{92}$ The first direct report of the fiddle and banjo playing together comes from Bill Whitlock, a white minstrel who recalls playing his banjo with a fiddle player named Dick Myers in $1840 .{ }^{93}$

\footnotetext{
${ }^{90}$ Farmelo, 195.

${ }^{91}$ Nicholas Cresswell, Journal of Nicholas Cresswell, 1744-1777 (New York: L. Macveagh, Dial Press, 1924), 30, ref. in Conway, "Black Banjo Songsters of Appalachia," 152.

${ }_{92}^{92}$ Conway, African Banjo Echoes in Appalachia, 153.

${ }^{93}$ Ibid., 112.
} 
The playing of the fiddle and banjo in ensemble was a significant event because it marked a stylistic change in the music of Appalachia. Thomas Carter argues that in the late nineteenth century there occurred a shift in mountain music from a preference for the solo fiddle to a preference for an ensemble format. Because of this, Appalachian music became less melodically complex and more rhythmically sophisticated. Carter concludes that the catalyst for this change in style was the fiddle and banjo ensemble. ${ }^{94}$

The next stylistic change in old-time music came when the mountain string band emerged in the early twentieth century. Farmelo identified three musical milestones that contributed to the advent of the mountain string band: the shared black and white banjo tradition, the disappearance of the black banjo from America's view, and the addition of the guitar to the fiddle and banjo ensemble. ${ }^{95}$ As was demonstrated above, the black-white banjo tradition goes as far back as the beginning of the nineteenth century, but after the Civil War the shared tradition began to diverge. ${ }^{96}$

For blacks in the late nineteenth century, the banjo had become a symbol of racism mostly because of its associations with minstrel stereotyping. Blacks became less interested in it as a result, and the black tradition of playing the instrument began to die away. Minstrelsy itself was virtually gone from American popular entertainment by 1920, and by the middle of the twentieth century the black banjo player stereotype was all but forgotten. Interestingly, by the late twentieth century the banjo had become a symbol of white hillbilly stereotypes. ${ }^{97}$

\footnotetext{
${ }^{94}$ Thomas Carter, “'I never could play alone': The Emergence of the New River Valley String Band, 1875-1915” in Arts in Earnest: North Carolina Folklife, ed. Daniel Patterson and Charles Zug III (Durham, N.C. : Duke University Press, 1990), 47-74, ref. in Wells, 143.

${ }^{95}$ Farmelo, 188.

${ }^{96}$ Ibid., 192.

${ }^{97}$ Ibid., 192-193.
} 
The next important development in the mountain string band tradition was the addition of the guitar to the banjo-fiddle combination. The guitar has been present in the United States since the colonial era but was long considered an upper-class parlor instrument. Throughout the South, as the guitar became widespread, the genteel classical style of playing the instrument was replaced with the finger picking styles developed by black musicians. In fact, the earliest mentions of the guitar by Southerners involve the instruments being played by black workers. It appears that the guitar did not reach the less accessible areas of the South, such as the mountains, until much later. $^{98}$

The blues and the guitar entered Appalachia sometime between 1890 and 1920. The musical form and the instrument were brought by blacks who had migrated to the mountains for coal mining work, railroad jobs, or other labor during this time, and there are accounts of African Americans playing the blues on guitar in Appalachia as early as $1904 .{ }^{99}$ Once in the mountains, the blues spread along the railroads, and eventually the Sears, Roebuck and Company mail order catalog made the guitar available and affordable to people in these rural areas. The instrument was added to the fiddle-banjo ensemble soon after the turn of the twentieth century and the mountain string band was born. ${ }^{100}$

Three characteristics of mountain string band music would become critical to the emergence of bluegrass music. First, the role of instruments in the ensemble began to be redefined. In the earlier fiddle-banjo ensemble neither the banjo nor the fiddle had a leading role over the other; both played the melody at the same time. When the guitar was added to the duo, this sound began to change, and each instrument took on a specific role. The fiddle played the

\footnotetext{
${ }^{98}$ Malone, 24.

${ }^{99}$ Barry Lee Pearson, “Appalachian Blues,” Black Music Research Journal 23, no. 1/2(Spring - Autumn, 2003): 35.

${ }^{100}$ Farmelo, 195.
} 
lead, the guitar played bass lines and the harmonic accompaniment, and the banjo provided the rhythmic drive. ${ }^{101}$ This division of roles would become a defining feature of bluegrass music.

Second, the wide variety of songs in the repertoire of these string bands anticipated that of later bluegrass bands. The songs recorded by the Skillet Lickers between 1926 and 1931, for example, consisted of traditional Appalachian songs and instrumental tunes but also popular music and early jazz. Though their recordings of these latter genres were not always successful, the fact that the Skillet Lickers attempted to incorporate such a wide variety of material shows a willingness to play music from any source. ${ }^{102}$

Finally, and most importantly, Appalachian string band music marked the point at which mountain musicians began to create a contrasting rather than blended ensemble sound. This concept of an ideal heterogeneous sound is a West African musical legacy brought to the New World by slaves. Samuel A. Floyd determined that the idea had influenced all African-American musical genres and all popular American music. ${ }^{103}$ As Hay has argued, "The heterogeneous sound ideal also influenced the development of 'white' Appalachian string-band and bluegrass music. In fact, this music played by white Appalachians is not so much white but, as Julio Finn or Henry Louis Gates would likely say, 'mulatto'., 104

\section{The Songs and Styles of Appalachian Music}

The musical characteristics that define bluegrass style developed out of the wide variety of genres and performance traditions that have become incorporated in country music throughout

\footnotetext{
${ }^{101}$ Brose.

${ }^{102}$ Norman Cohen, “The Skillet Lickers: A Study of a Hillbilly String Band and its Repertoire," The Journal of American Folklore 78, no. 309, Hillbilly Issue (July - September, 1965): 229.

${ }^{103}$ Samuel A. Floyd, Jr. The Power of Black Music, (New York: Oxford Press, 1995), 54.

${ }^{104}$ Hay, 13-14.
} 
its history. While the original source of Southern music may very well have been mostly Celtic, because of the cultural intermixing between English, Scotch, Irish, and Welsh in the Southern frontier, it is almost impossible to determine the exact origin of any one song or style. Furthermore, the British settlers absorbed songs and styles from other cultural groups, particularly African Americans, with whom they coexisted. ${ }^{105}$ In Appalachia the folk music of the Scotch-Irish blended with the folk music of African Americans, and it was this new music that came to define the "high, lonesome sound" of bluegrass. ${ }^{106}$

When country music began its commercial development in the 1920s, musicians drew upon the storehouse of religious, secular, southern, non-southern, folk, and popular songs that existed in the Southern canon. The core of this repertoire consisted of traditional British and American songs, particularly ballads. Ballads are songs that tell a story. These songs remained in Southern culture as part of a comfortable and familiar tradition. Even when specific songs were forgotten, the form and spirit of the ballad tradition remained and persisted into modern country music. $^{107}$

The study of these folk ballads began in the twentieth century. The Englishman Cecil Sharp was one of a new breed of folk music collectors interested in the examination of existing sources and the collection of material in the field. On a 1915 trip to the United States, Sharp met another collector of folk song, Olive Dame Campbell. Years before meeting Sharp, Campbell had begun to collect folk songs in the Appalachian Mountains. She encouraged Sharp to come to the region and do the same. In July, 1916, Sharp traveled to western North Carolina and began to collect songs in what he described to Campbell as, "the richest field," in which he had ever

\footnotetext{
${ }^{105}$ Malone, 3-4.

${ }^{106}$ Cantwell, 115-116.

${ }^{107}$ Malone, 14.
} 
collected. Sharp and Campbell's joint publication the following year, English Folk Songs of the Southern Appalachians, was the first major scholarly collection of the music of the mountain people. Through their research, Sharp and Campbell proved that the folk music they had collected in Appalachia was of British origin.

Sharp's exclusive interest though, was in preserving and collecting traditional English ballads, and folk music from other origins meant little to him. His limited interest blinded him to emerging new styles in the mountains. ${ }^{108}$ It also seems to have prevented him from noticing the fact that the ballad tradition itself was undergoing a change in Appalachia. Though Sharp did not fully realize it at the time, mountain ballads had absorbed some of the rhythmic and melodic characteristics of black music.

Sharp did observe an anomaly in Appalachian music that did not exist in the British folksong tradition. He describes it in his notes about the folksongs he collected:

They have one vocal peculiarity, however, which I have never noticed amongst English folk-singers, namely, the habit of dwelling arbitrarily upon certain notes of the melody, generally the weakest accents. This practice, which is almost universal, by disguising the rhythm and breaking up the monotonous regularity of the phrases, produces an effect of improvisation and freedom from rule which is very pleasing. ${ }^{109}$

Hay argued that this "peculiarity," which is likely a reference to syncopation and improvisation, is also found in African-American music, such as blues, jazz, and gospel music, as well as the music of West Africa. ${ }^{110}$

Black melodic characteristics also entered the Appalachian folk tradition. Cantwell theorized that one of the reasons this happened is because of similarities between the modes used

\footnotetext{
${ }^{108}$ Crawford, 598-603.

${ }^{109}$ English Folk Songs from the Appalachians: Comprising 122 Songs and Ballads and 323 Tunes, comp. Olive Dame Campbell and Cecil J. Sharp. (New York: G.P. Putnam's Sons, 1917), x. quoted in Hay, 8.

${ }^{110}$ Hay, 8 .
} 
in Celtic music and those used in West African music. The major pentatonic scale, for example, is found in the music of many cultures. The scale was sometimes called the "African" pentatonic because it is heard in so many African-American spirituals, such as "Swing Low Sweet Chariot" and "Nobody Knows the Trouble I've Seen." Henry Edward Krehbiel was the first to identify that this pentatonic scale was a shared characteristic of African and African-American music. He claimed that the major pentatonic scale is possibly the oldest and most ancient arrangement of tones, and he noted that it exists in Scottish music as well. ${ }^{111}$

Cantwell notes the similarity between what Marshall Stearns calls "blue tonality" and the modes of British folk music. Blue tonality refers to the tendency of spiritual singers, blues musicians, jazz players, and even mountain musicians to play or sing the third or seventh of the scale as somewhere between what Europeans would think of as major or minor. ${ }^{112}$ AfricanAmerican musicians were responsible for teaching white musicians to sing and play these "inbetween notes" and to explore their expressive power. The mixolydian mode, characteristic of English folk music, shares the flatted seventh with the blues tonality. Appalachian musicians also usually add a minor third when playing a mixolydian tune like "Little Maggie." The dorian mode and blues are also similar, differing by only a half step. For Cantwell, these melodic similarities shared by the cultures aided the combining of the two musical traditions. ${ }^{113}$

\footnotetext{
${ }^{111}$ Henry Edward Krehbiel, Afro-American Folksongs: A Study in Racial and National Music (New York: F. Ungar, 1913, 1974), 74, 93, ref. in Cantwell, 120.

${ }_{112}$ Marshall Stearns, The Story of Jazz, (New York: Oxford University Press, 1956), 138, ref. in Cantwell, 121.

${ }^{113}$ Cantwell, 120-122.
} 


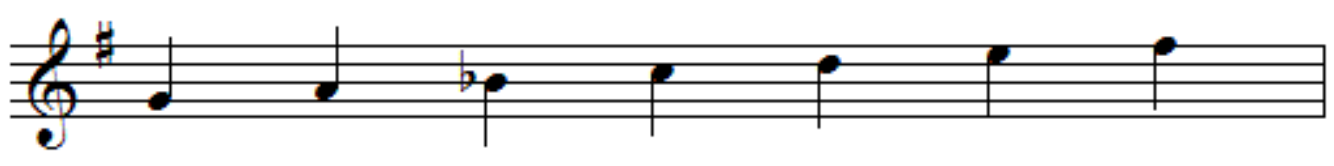

Ex. 2.1 Dorian mode beginning on $\mathrm{G}$.

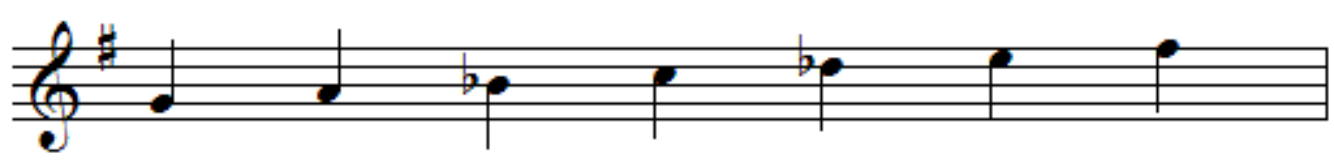

Ex. 2.2 Blues scale (with diatonic additions) beginning on $\mathrm{G}$.

Religion and religious music have been an integral part of Southern society and therefore became an essential part of country music and bluegrass. Religious practice influenced every facet of southern life and no doubt shaped the way secular songs were performed. ${ }^{114}$ As mentioned above, a great deal of contact between blacks and whites occurred during the camp meetings that characterized the Great Revival (Second Awakening) of the early 1800s. ${ }^{115}$

Bill C. Malone argued that the music made at these meetings transformed the music of all southern Protestants. Congregational singing was a central part of these gatherings, and meeting leaders would set simple texts to folk or popular tunes that would have been familiar to the crowd. They would add repeating choruses, line the hymn, ${ }^{116}$ and change the old colonial-era hymns so that they could be easily sung by the masses. As country music developed, these same characteristics - simple lyrics, straightforward melodies, memorable choruses, refrains, and repetitive phrases, harmony based on shape-note hymnody_-became a part of the music. ${ }^{117}$

The popularity of these camp meetings declined because the southern frontier transformed into a farming society in the nineteenth century, Nevertheless, the spirit of the Great

\footnotetext{
114 Malone, 10.

115 Ibid., 199.

116 "Lining a hymn" is a musical practice in which two lines of a hymn are sung by a soloist and then repeated by the congregation.

${ }^{117}$ Malone, 10-11.
} 
Revival remained in many southern Protestant churches. The sources of southern religious music throughout the nineteenth century were as varied as traditional British hymnody, American revivalism, shape-note singing, anonymous folk composers, African-American sources, and the gospel composers of post-Civil War America. ${ }^{118}$

The close vocal harmonies sung by bluegrass musicians most likely came from the church music that they grew up singing. In fact, most bluegrass bands dedicate a portion of their repertoire to religious music. This music is usually sung a capella in four- or five-part harmony. ${ }^{119}$ This style of arrangement was pioneered by the gospel vocal groups that appeared in the nineteenth century and continues to this day. The original gospel groups were the brainchild of J.D. Vaughn who conceived the gospel quartet as a way to promote his shape-note hymnals. The Vaughn quartets and their imitators popularized this harmonized style of singing throughout the South through performances, singing schools, and all-day singing conventions. ${ }^{120}$

Other sources of early country music were the dance tunes, instrumental numbers, and bawdy songs of English frolic traditions. Added to these were jigs, reels, hoedowns, and other pieces from Celtic and African-American cultures. Though they may have originally had folk origins, many styles and songs came to the South through professional entertainers such as songand-dance men, black-face minstrels, or vaudeville performers. Hornpipes, which are played by every fiddler, were originally tunes played to accompany dances. The Virginia Reel and the square dance were derived from upper-class dances that made their way from the plantations to the rural poor. ${ }^{121}$

\footnotetext{
${ }^{118}$ Malone, 11-12.

${ }^{119}$ Henry L. Carrigan, Jr., "Bluegrass," in Encyclopedia of Gospel Music, ed. W.K. McNeil (New York: Routledge, 2005).

${ }^{120}$ Malone., 21.

${ }^{121}$ Ibid. 16-17.
} 
Urban music was brought to rural areas of the South by the blackface-minstrel show in the nineteenth century. Minstrels brought tunes such as "Old Zip Coon ("Turkey in the Straw")," "Blue-Tailed Fly," "Yellow Rose of Texas," and "Old Dan Tucker," into the country music repertoire. ${ }^{122}$ Other urban vocal genres, like the parlor song of the late nineteenth century and the Tin Pan Alley tunes of the early twentieth eventually came into country music as well. Though these songs were initially aimed at the upper-middle class, some became popular throughout the nation, and by the 1920s these tunes formed one of the largest categories of songs found on early country music records. ${ }^{123}$ As Malone put it, rural Southerners would incorporate any song that they liked into early country music. They responded to any song as long as it shared their values of, "home, family, mothers, and God.", 124

\section{Hillbilly Music}

Bill Monroe began his career as a hillbilly music star. Along with his brother Charlie, he became popular in the Piedmont and Appalachian regions of North Carolina between 1935 and 1939. In order to understand the emergence of bluegrass, we must examine this early commercial country music genre and understand what it was like in the 1930s when the Monroe Brothers began playing it. ${ }^{125}$ Furthermore, because most of the songs recorded by these early hillbilly musicians came from the old-time mountain tradition or gospel songs, examining early commercial country music will illuminate the cross-cultural heritage of bluegrass. We need only

\footnotetext{
${ }^{122}$ Ibid., 8.

123 Ibid., 15-16.

124 Ibid. 16.

${ }^{125}$ Rosenberg, 18.
} 
look at the singing and playing styles of the first country music stars, Jimmie Rodgers and the Carter family, to see the enduring influence of black musicians.

The term "hillbilly" was first used to describe the music of the rural south in 1925. The term came from the naming of Al Hopkins's band by Ralph Peer. After recording six numbers by the band, Peer suggested that they decide on a name. Hopkins replied, "Call the band anything you want. We are nothing but a bunch of hillbillies from North Carolina and Virginia anyway." ${ }^{126}$ Record companies rarely used the term for marketing purposes, but instead it came into use because of musicians, fans, critics, and detractors. Despite the negative connotations held by the term, it is now widely used to refer to the Southern rural music that was first recorded in the late 1920 s. ${ }^{127}$

The origins of old-time music have been explored in detail above, but it is also important to understand the musical characteristics of hillbilly music as well as the social and cultural conditions in which it was performed. First, most of the people involved with early commercial country music were young white Protestants, and most of the performers were young men. The majority of these people were in the process of moving away from their rural roots to industrial jobs in urban and suburban settings. Often, these new immigrants would move in with family members and old neighbors who had migrated earlier. They would often have contact with others from their original homes.

The radio and phonograph were not common in these new communities until the 1930s. If migrants wanted to hear music they would play it themselves or find someone else in the community who could. Music was a part of social interactions and was shared with family and neighbors. Everyone sang and most people were able to play an instrument. Old-time music was

\footnotetext{
${ }^{126}$ Malone, 41.

${ }^{127}$ Ibid., 41-42.
} 
the vernacular musical tradition of these communities, and when the first hillbilly artists recorded it, their records became wildly popular among these groups.

The Great Depression began to cut down on the number of people who moved from the farm to the city, but many continued to do so. The young men who moved during this time created the professional hillbilly music of the Piedmont region. Like those who had migrated earlier, these men moved from their family farms to small and medium sized towns that offered mill and factory work.

Many who moved to these areas brought music with them, and as they arrived in their new homes they were immediately sought out by others in the community who played music. Because the Depression made regular jobs harder to come by, jobs in music became more appealing than they had been before. These new professional musicians preferred to perform in groups rather then alone.

The hillbilly bands of the thirties were also looser in structure and sound than the later bluegrass bands. Most members had specialty roles within the band such as that of the comedian, instrumental soloist, or solo vocalist. So-called "brother duets" were a common genre of song; these were vocal duets sung by two men who were cousins or brothers. Religious quartets were also sung by these early bands. As we have already seen, this type of performance was made popular by traveling gospel quartets sponsored by religious music publishers. Most importantly, some of the most influential gospel groups were made up of black performers.

Unlike the gospel music that inspired it, singing in hillbilly bands was never unaccompanied. All hillbilly bands were made up of string instruments, but the instrumentation of these groups varied widely. Most bands, though, inherited the legacy of the mountain string band which, as we have seen, consisted of a fiddle, five-string banjo, and guitar. Sometimes, 
other instruments such as the mandolin were present in these bands. These instruments had been popular with the urban middle-class several decades earlier and were gaining prominence in the Piedmont region.

Hillbilly performances were theatrical by nature, and all of the band members dressed in costume. The outfits of the musicians often matched; this manner of dress contributed to a specific image that the band was trying to create. Common images were cowboy duds, exaggerated rural dress, and expensive clothing typically worn by bankers. In addition to songs and comedy, these performances included direct sales pitches to the audience for the band's merchandise or products offered by the band's sponsor. Bands often had non-musician partners, such as emcees or managers.

A band's professional career was often launched by a local public performance or an appearance on the radio. Radio appearances were rarely directly profitable as most bands were not paid for their time. Instead, this medium was valuable because it offered an extremely important advertising opportunity for the band's concerts and appearances. Like the radio, records were rarely profitable for the hillbilly artists that recorded them. Royalty contracts were rare, and bands were often paid a flat fee for their time in the recording studio. Performers did not often sell their records at their live shows because the size and weight of 78rmp records made it impractical to transport them. The true value of the recording medium, like radio, was in its ability to increase a band's popularity. ${ }^{128}$

Even though they were not financially lucrative for performers, radio programs and recordings were extremely profitable for record executives and station owners. In fact, it was because of these new formats that country music evolved into a commercial industry between

${ }^{128}$ Rosenberg, 18-26. 
1920 and 1925. Radio stations began to broadcast local performers, and these shows came to be called "barn dance" programs. By 1925, these types of broadcasts, such as the WSM Barn Dance from Nashville (which would later become the Grand Ole Opry), were well established. Around the same time, record companies began to produce and sell hillbilly records. OKeh Records executive Ralph Peer went to Atlanta in 1923 and recorded the singing and playing of Fiddlin' John Carson. The record he created there became a commercial success, and in 1927, Peer traveled to the Clinch Mountains of Virginia and Tennessee to record Jimmie Rodgers and the Carter Family. ${ }^{129}$

\section{Jimmie Rodgers and the Carter Family}

The recording session in Bristol would prove to be a seminal event in country music history. In the first four days of August in 1927, both Jimmie Rodgers and the Carter Family recorded albums for Ralph Peer. Rodgers and the Carters had been attracted to the session by an advertisement in a local newspaper, and of the many acts that recorded in Bristol at that time, they were the only ones to go on to have lasting commercial success.

Though both were considered to be hillbilly artists, the music and image of Rodgers and the Carters were very different from each other. Rodgers exuded the image of a rambler, someone who had been everywhere and had seen everything. He put that experience into his songs. The Carters, on the other hand, represented home and stability. Their music brought forth memories of the old country church and family. To early country music fans, one image was just

${ }^{129}$ Crawford, 607. 
as appealing as the other. ${ }^{130}$ These fans, mostly white, may have been surprised to learn that the music of Rodgers and the Carters were directly influenced by African Americans.

Jimmie Rodgers was born in 1897 in Meridian, Mississippi. Though he was not from Appalachia, his deep-Southern accent and the fact that he became popular during the hillbilly craze of the 1920s, ensured that he would became famous for singing this style of music.

Rodgers was the first country singing star, and he brought new techniques and songs into the country music canon. His records helped establish, among other things, the popularity of the "blue yodel" and helped ensure a place for the blues in country music. ${ }^{131}$ Jimmie Rodgers also directly affected the sound of bluegrass music. Some of Bill Monroe's first successful recordings were versions of Jimmie Rodgers's songs.

Rodgers's blue-yodel technique stands as a testament to the debt that early hillbilly musicians owe to the music of black Americans. Yodeling is actually as common in African folk music as it is in European folk music, and traces of it can be seen in the field-hollers of African Americans. John Edward Phillips asserts that this black style of singing had an influence on Jimmie Rodgers who was raised in an area where the majority of the population was black. Other aspects of his singing, such as his version of the blues, also show a strong black influence. ${ }^{132}$

The Carter Family band, which consisted of Alvin Pleasant (A.P.) Carter, his wife Sara, and his sister-in-law Maybelle Addington Carter, was extremely popular from the late 1920s into the 1940s. By the time Ralph Peer came to Bristol to record them, they had established a musical presence in southwest Virginia. The Carters made a significant contribution to the country music repertoire creating over three hundred recordings during their long career. Even today, the songs

\footnotetext{
${ }^{130}$ Malone, 64-65.

${ }^{131}$ Ibid., 77.

132 John Edward Phillips, "The African Heritage of White America," in Africanisms in American Culture, ed. Joseph E. Holloway, (Bloomington: Indiana University Press, 1991):.230
} 
that they recorded are played by country and bluegrass musicians. The singing style and instrumental techniques found in the music of the Carters had a lasting influence on later country musicians. $^{133}$

One of the key elements of the Carter's sound was the guitar technique of Maybelle Carter. Her style, known as the "Carter scratch" or "the church lick" involves striking a single lead note with the thumb and brushing the other strings with the index finger, each equipped with fingerpicks. This technique is similar to black banjo playing and it is very likely that Maybelle Carter learned it from African Americans. ${ }^{134}$ It is well documented that a black musician named Leslie Riddle influenced Maybelle Carter's guitar style and also taught A.P. Carter many songs. ${ }^{135}$ Dock Boggs, a white old-time banjo player who learned his music directly from African Americans, possibly taught Maybelle Carter this technique. ${ }^{136}$

Maybelle Carter also played the guitar in other styles. One of these was called "Hawaiian" (because of its similarity to Hawaiian slack key guitar playing) and involved placing the guitar flat on her lap and using a pocketknife to fret the strings. This style was also played by Leslie Riddle, and it is possible that he taught it to Carter. Another technique called flat-picking used a single plectrum instead of the thumb and finger picks of the "Carter scratch." She most likely got this style from her brother "Doc" Addington. Her other style was a ragtime fingerpicking technique that was also learned from Riddle. Here, an alternating bass line is played by the thumb, and the melody is picked on the higher pitched strings with the index finger. Of the

\footnotetext{
${ }^{133}$ Malone, 65-66.

${ }^{134}$ William E. Lightfoot, “The Three Doc(k)s: White Blues in Appalachia," Black Music Research Journal, 23, no. 1/2 (Spring- Autumn, 2003): 180.

135 Hay, 8.

${ }^{136}$ Lightfoot, "The Three Doc(k)s.” 180.
} 
four techniques that Addington relied upon, three can be attributed directly to an AfricanAmerican influence.

The biggest debt that the Carters owed to black music is apparent in their repertoire. Religious music, such as spirituals and gospel tunes, comprised forty percent of their repertoire, and half of those songs came from black sources. Some songs like "Little Moses" and "When the World's on Fire" were taken directly from black musicians or learned from recordings. Other songs like "I Wouldn't Mind Dying" or "Motherless Children" were all based on AfricanAmerican models.

The Carters also played blues-type songs. William E. Lightfoot notes that while most of these songs are not authentic blues, "Hello, Stranger," "Jealous Hearted Me," "Coal Miner's Blues," "Bear Creek Blues," and "Lonesome Homesick Blues" come the closest. These songs are, “...constructed out of bits and pieces of the blues—-harmonic patterns, a certain amount of melancholy, and occasional use of the blues scale." They are not truly blues though because they lack, "a twelve-bar structure of 4/4 time, are certainly not slow, are not meticulously timed, do not use fluid intonation, and are absent of any kind of antiphonal activity." ${ }^{\prime 17}$ The Carter's blues then, are not the same as black blues, but should be considered a separate style which Lightfoot terms "white blues."138

The Carter's adaptation of the blues is typical of an on-going process occurring in Appalachian folk music around the same time. In his study of the group's recording of "Coal Miner's Blues," Archie Green has noted that white Appalachians have been incorporating black

\footnotetext{
${ }^{137}$ Ibid., 184.

${ }^{138}$ Ibid., 181-184.
} 
blues into their music at least since the first hillbilly recordings were made in $1923 .{ }^{139}$ White Appalachian musicians admired many African-American folk music styles and attempted to incorporate them into their music. Some styles and genres, such as ragtime and religious songs, were more easily assimilated than others. The white adaptation of the blues, on the other hand, retained only certain elements of its black counterpart. Only the structure, harmonic patterns, lyrical content, and tonality survived the transfer. ${ }^{140}$ These surviving elements of the blues would in turn come into bluegrass music when it developed nearly a decade later.

Even the deepest roots of bluegrass were formed by the mixture of West African and European music. This blending of black and white traditions occurred when the European fiddle and the African banjo were first played together. The guitar, and the black playing styles that came along with it, was later added to the pair, and the foundation of the mountain string band was laid. This ensemble, which demonstrated a heterogeneous sound ideal, had elements of black and white music and would later develop into the bluegrass band.

The style of bluegrass music has as its base the ballads and other folk music that came to Appalachia with the original Scotch-Irish settlers. But even this seemingly pure-white legacy was at some point transformed by the influence of African Americans, an influence that begins certainly by the late $17^{\text {th }}$ century. During the nineteenth century, music in the mountains absorbed other elements from a variety of sources such as black and white religious music, dance tunes, minstrel songs, ragtime, and tunes from Tin Pan Alley.

\footnotetext{
${ }^{139}$ Archie Green, “The Carter Family's “coal miner's blues,"” Southern Folklore Quarterly, 25 (1961): 231, quoted in Lightfoot, 167.

${ }^{140}$ Lightfoot, "The Three Doc(k)s," 167.
} 
These early songs and styles came to be called "old-time" music in the twentieth century. When commercial country music developed in the 1920s, old-time music formed the majority of the repertoire. The hillbilly music of artists like Jimmie Rodgers and the Carter Family became extremely popular and the music they played had a lasting effect on later country music. As they did on the earlier folk styles, African Americans had an influence on this beginning stage of country music. Jimmie Rodgers's blue yodel and the Carter Family's instrumental and vocal styles reflect the legacy of black musicians.

Bill Monroe grew up playing old-time music and became an extremely successful professional hillbilly musician. The new music he created in the 1940s inherited the black and white musical traits already present in the old-time music he grew up playing. The next chapter explores the black music that had a direct influence on Monroe, specifically through the guitar player Arnold Shultz. It also attempts to prove that there was an African-American influence, albeit indirect, on the three-finger banjo playing style of Earl Scruggs. 


\section{CHAPTER 3}

\section{BILL MONROE, EARL SCRUGGS, AND THE BLACK INFLUENCE ON BLUEGRASS MUSIC}

The inventor of the bluegrass style, Bill Monroe, grew up playing old-time music and began his career as a hillbilly musician. His early life and later musical thinking were shaped by the black and white styles he encountered in Kentucky in the early twentieth century. When bluegrass developed in the 1940s, it bore the legacy of these two musical cultures.

The exact date that Monroe's music ceased to be "old-time" or "hillbilly" and became "bluegrass" is a contentious issue among scholars. There are three opinions regarding that date at which bluegrass came to be. One school of thought is that the music emerged fully formed when Bill Monroe and the Blue Grass boys began working at the Grand Ole Opry in 1939. Others argue that bluegrass developed sometime between 1945 and 1948 when Earl Scruggs added his banjo to Monroe's sound. Still others, like Neil Rosenberg, contend that bluegrass truly became a style sometime in 1947 or 1948 when other bands, particularly the Stanley Brothers, deliberately began to copy the sound of the Blue Grass Boys. ${ }^{141}$

Black music directly affected bluegrass at least twice in its history. The first direct influence was on the young Bill Monroe and happened through his interaction with musicians like Arnold Shultz. Black music also touched the banjo playing of Earl Scruggs. Though there is

\footnotetext{
${ }^{141}$ Rosenberg, 10-11.
} 
no documented evidence of Scruggs learning from a black banjo player, his three-finger style developed out of a synthesis of black and white banjo styles.

\section{Bill Monroe}

Bill Monroe was born on September 13, 1911 near Rosine, Kentucky, the youngest in a family of farmers. His mother died when he was only ten years old, and his father died when he was sixteen. By the time he was seventeen, both of his older brothers had left to find work away from the farm, and Monroe was left on his own. ${ }^{142}$

Monroe told James Rooney that hard work was common place on his family's farm, and that there were no radios or other opportunities to hear music unless it was played by a member of the family or someone else in the community. Monroe was born with weak and crossed eyes but also with keen ears and was observant to the sounds that were occurring around him. These sounds of his childhood formed the basis of his musical development. ${ }^{143}$

The earliest musical experiences in Monroe's life were similar to those of other young, white Southerners in the early twentieth century. According to Rosenberg, "The family music at home, church-sponsored singing schools, apprenticeship to older dance musicians, and contacts with black musicians...were typical musical experiences for a rural southern white youth of the time." ${ }^{144}$ Monroe's bluegrass music was shaped by the old-time music, religious singing, and black bluesmen that he encountered as a young man. He also had two role models in his early

\footnotetext{
${ }^{142}$ Rooney, 35 .

${ }^{143}$ Ibid., 35-36.

${ }^{144}$ Rosenberg, 29.
} 
life, musicians whom he would later credit as having a significant influence on him: his Uncle Pendleton "Pen" Vandiver and a black guitarist named Arnold Shultz. ${ }^{145}$

Old-time traditions were a part of the Monroe household. His father was a fine dancer, and his mother sang folk songs and ballads and played the harmonica, button accordion, and fiddle. Bill Monroe's uncle, Pendleton Vandiver, played the fiddle at dances in the community. All of Monroe's siblings played instruments, but the four youngest children were the most involved in music. His brother Birch played the fiddle, his brother Charlie and sister Bertha played guitar. Monroe began to play the mandolin and guitar at age eight or nine. ${ }^{146}$

The first music that Monroe recalled hearing was played by his Uncle Birch Monroe ${ }^{147}$, Uncle Pen, and another man named Clarence Wilson. He told Rooney that the song they played was an old fiddle tune called "Soldier's Joy." He also remembered another group called the Foster Band that consisted of a fiddle, dobro, mandolin, and possibly banjo. This group played breakdowns, waltzes, and a little Hawaiian music. He also recalls traveling to a place called "The Liza House" where he heard a fiddler named Clea Baze play numbers like "Turkey in the Straw" and "Cacklin' Hen." 148

At these kinds of gatherings the music Monroe heard was meant for dancing and was mostly instrumental. He was also influenced by the music he grew up singing in the Baptist and Methodist churches of Rosine. Because of his poor vision, Monroe learned the traditional shapenote hymns by ear. ${ }^{149}$ These hymns, part of the Sacred Harp tradition, had a certain "open"

\footnotetext{
${ }^{145}$ Rooney, 37.

${ }^{146}$ Rosenberg, 28.

${ }^{147}$ Bill also had a brother named Birch Monroe.

${ }^{148}$ Rooney, 36.

${ }^{149}$ Rosenberg, 28.
} 
harmonic quality. This sound would later come to define the vocal harmonies of Monroe's "high lonesome sound."150

The black musical traditions in Kentucky had a profound effect on the young Monroe. ${ }^{151}$ The blues in particular had an influence on bluegrass, and Monroe told Rooney of a black man that he had heard in Rosine who whistled the blues while he worked. This man seems to have made strong impression on Monroe who remarked, "He would be riding his mule on those muddy roads just whistling the blues. And you could tell by the way he whistled that he was the bluest man in the world." 152

Another person who had a profound influence on Monroe was his uncle Pen Vandiver. After his own family had passed away, Uncle Pen came to live with the Monroes. Once Monroe's own family had died or left, Uncle Pen became a major role model for Bill. ${ }^{153}$

Not much is known about Uncle Pen's life other than what Monroe has told interviewers and biographers. He was a farmer and played the fiddle his entire life. After his family died, he became something of a rambler. Though he stayed with Monroe's family he wandered freely, often trading goods and livestock to make a little money. Monroe also makes it clear that Pen was always fair when they played gigs together. Even though Pen was much older and more experienced, he would always split the earnings evenly with Monroe. ${ }^{154}$

Monroe would later write a musical tribute to his uncle called "Uncle Pen." The song captured the spirit and playing style of the old-time dance music that Monroe first played with him. In fact, when Monroe would play this tune on stage he would perform an old-time dance

\footnotetext{
${ }^{150}$ Rooney, 36.

${ }^{151}$ Rosenberg, 28.

${ }_{152}$ Rooney, 36-37.

${ }^{153}$ Ibid., 38.

${ }^{154}$ Ibid., 38.
} 
routine. ${ }^{155}$ Monroe said of Uncle Pen's playing: "He had the best movement with a fiddle bow that you have ever seen in your life. He could really shuffle. A lot of Uncle Pen's fiddling is in bluegrass music...you know when he was young that he was a wonderful old-time fiddler. It's got its part in bluegrass music." 156

Later when Monroe was coaching the fiddle players of the Blue Grass boys, he would recall from memory the exact notes and melodic phrasing of his uncle's fiddle playing. Furthermore, the spirit of these dance tunes formed part of the rhythmic backbone of bluegrass. ${ }^{157}$ By asking his fiddlers to play like his uncle did, Monroe was transferring the oldtime style into his music. He was also transferring the black and white musical traits that formed the old-time style.

Another man who had a significant impact on Monroe was the black musician Arnold Shultz. Monroe first saw Shultz at a square dance in Rosine. His band had a guitar, banjo, and a fiddle. Shultz himself played guitar and occasionally the fiddle. Monroe recalled him playing old-time fiddle tunes like "Sally Goodin'."158

Like Uncle Pen, not much is known about the life of Arnold Shultz. Recently though, his apparent influence on bluegrass and other styles of country music has sparked a renewed interest in his life among scholars. Shultz was born in February of 1886 to David and Elizabeth Shultz. Accounts give his place of birth as the town of Cromwell or the Taylor Mines mining camp two miles south of Beaver Dam, Kentucky. ${ }^{159}$ It is known that Shultz's father was born into slavery

\footnotetext{
${ }^{155}$ Stephanie P. Ledgin, Homegrown Music: Discovering Bluegrass (Westport Connecticut: Praeger, 2004$), 70$.

156 Rooney, 38.

157 Ledgin, 19.

158 Rooney, 37.

${ }^{159}$ William E. Lightfoot. "A Regional Style: The Legacy of Arnold Schultz.” in Sense of Place: American Regional Cultures, ed. Barbara Allen and Thomas J. Schlereth (Lexington: University Press of Kentucky, 1990), 126.
} 
but his mother Elizabeth, who had Arnold when she was sixteen, was born a free woman. ${ }^{160}$ Members of the family would play together for regional events like brush dances and taffy pulls. Arnold learned his music at home, and while known to have played fiddle, banjo, mandolin, and piano, he received his main instrument, the guitar, when he was fourteen. ${ }^{161}$ Shultz was working as a coal miner and as a musician in western Kentucky by his teens. ${ }^{162}$

The Shultz Family Band, which included Arnold's relatives Luther, Hardin, Ella, and Arnold himself, was an old-time or hillbilly band. As we have seen, the black roots of country music are often ignored, so it is significant that this black family band played hillbilly music. Band member Ella Shultz Griffin explained, "It was called hillbilly music then, and it was hillbilly too, but it was what we knew, all I had ever heard.” The band played all over Kentucky's Ohio County, and Griffin even recalls playing a dance in Rosine, Monroe's hometown. ${ }^{163}$

Shultz absorbed the old-time music that he was playing with his family as well as with white musicians, but he also took in black folk traditions like blues, rags, breakdowns, gospel tunes, and guitar styles. Several regional musicians remember Shultz pulling the strings to create a pitch bend, or playing an open-tuned guitar with a bottleneck or knife to "fret" the strings — all techniques from the black tradition. ${ }^{164}$

Though racial segregation certainly existed in this part of Kentucky, musicians often crossed these barriers. Shultz, for one, eventually played with an otherwise all-white band led by

\footnotetext{
${ }^{160}$ Keith Lawrence, “Arnold Shultz: Godfather of Bluegrass?” Bluegrass Unlimited , 24 (November 1989): 40.

${ }^{161}$ Lightfoot, "A Regional Style," 127-128.

162 Lawrence, 40.

163 Ibid.

${ }^{164}$ Lightfoot, “A Regional Style,” 130-131.
} 
Forrest Faught. The bandleader recalled that Shultz was frequently teaching other musicians licks he had come up with:

Back then everybody just used three chords (G, C, and D). That's about all anybody knew how to play. That night we were playing 'See You in My Dreams.' Arnold showed us where to put that A chord in there. From then on, we used the A chord in 'See You in My Dreams' and a lot of other places. ${ }^{165}$

In an effort to document Shultz's playing style, William E. Lightfoot compiled

various anecdotes and stories about the musician as told by his contemporaries in western Kentucky. Musicians like Ike Everly and Nolin Baize remembered the way Shultz played ragtime music on his guitar. Everly recalls learning "Cannonball Rag” from Shultz. Baize commented that he made the guitar sound like a piano. This statement most likely refers to Shultz's finger-picking technique which imitated the alternating bass line and chords of the pianist's left hand and the syncopated melody of the pianist's right hand. According to Lightfoot, Shultz's ragtime technique laid the foundation for a later style known as "Travis Picking." Other musicians, like Tex Atchison of the Prairie Ramblers and Forrest Faught confirm that Shultz was the first guitarist they had encountered who could play the melody, harmony, rhythm, and accompaniment simultaneously. ${ }^{166}$

The guitar style known as "Travis Picking” has long been acknowledged as one of the most important and ubiquitous instrumental techniques in country music. Charles Wolfe stated that, the style developed in the western Kentucky coal fields in the 1930s and by 1950, had become the, "...dominant picking style in country music everywhere, thanks to the skill of its two most famous practitioners, Merle Travis and Chet Atkins.",167

\footnotetext{
165 Lawrence, 41.

${ }^{166}$ Lightfoot, "A Regional Style," 131-132.

${ }^{167}$ Charles K. Wolfe, Kentucky Country: Folk and Country Music of Kentucky (Lexington: University Press of Kentucky, 1982), 109 quoted in Lightfoot, "A Regional Style," 121.
} 
The technique allows a guitarist to play a melody, harmonic accompaniment, percussive rhythm, and a bass line simultaneously. Lightfoot identified six characteristics that define the style:

1. A constant alternating bass line played with a thumb pick. Each bass note is played on the first and third beats of a measure.

2. An offbeat chord, also played by the thumb. This lighter off beat chord not only provides the harmonic backing for the melody but also rhythmic foundation of the song.

3. A syncopated melody line played by the index finger.

4. The overall texture of the syncopated melody over a dampened (with the palm of the right hand) bass line and "choked" chord (dampened with the fingers of the left.)

5. A collection of regional "licks," like ornaments played by the little finger, walking bass runs, and rolls.

6. A general philosophy of applying the technique to songs from wide range of genres including rags, blues, breakdowns, ballads, hymns, Tin Pan Alley tunes, and sentimental parlor songs. $^{168}$

When put together, these elements create a texture that sounds like multiple guitarists are playing at once. In fact, many of the people who first heard Travis on the radio in the late thirties and early forties thought they were listening to just such an ensemble. As mentioned above, this same description was the response that many had upon hearing Arnold Shultz in western Kentucky as early as $1918 .^{169}$

The style was named for Merle Travis who originally learned it from the coal minermusicians he grew up with in western Kentucky. The musicians of this community, such as

\footnotetext{
${ }^{168}$ Lightfoot, “A Regional Style,” 122-123.

${ }^{169}$ Ibid., 123.
} 
Travis's mentor Mose Rager, had all been influenced, either directly or indirectly, by the exceptional musicianship and guitar playing of Arnold Shultz. ${ }^{170}$

In his wanderings around western Kentucky, Shultz spread his techniques to others. His personal style became rooted in the places he traveled, and in the last thirteen years of his life Shultz became a folk hero. The link between Shultz and Travis picking was forged in 1918 when Kennedy Jones heard Shultz play in a Central City tavern. Jones became obsessed with Shultz's style and spread the finger-picking technique throughout the region. Jones passed it on to people like Ike Everly and Mose Rager and many others, all of whom influenced Merle Travis, who spread the technique to Evansville in 1936 and from there to the world. Arnold Shultz, however, did not live to see this happen, having died in $1931 .{ }^{171}$

Shultz is known to have worked with the banjo player Clarence Wilson whose band included Monroe's uncle Pen Vandiver, and Monroe himself began following Shultz to dances in 1924 when he was only twelve. ${ }^{172}$ Monroe listened to Shultz talk about other dances he had played and contests he had won. Monroe came to admire Shultz a great deal and told Rooney:

There's things in my music, you know, that come from Arnold Shultz-runs that I use in a lot of my music. I don't say that I make them the same way that he could make them 'cause he was powerful with it. In following a fiddle piece or a breakdown, he used a pick and he could just run from one chord to another the prettiest you've ever heard. There's no guitar player today who can do that. I tried to keep in mind a little of it — what I could salvage to use in my music. Then he could play blues and I wanted some blues in my music too, you see. ${ }^{173}$

From this statement it is clear that Shultz's playing influenced Monroe's thinking about music. He specifically credits Shultz with exposing him to the blues and references its role in bluegrass. He also mentions Shultz's guitar playing, specifically the melodic licks he remembers

\footnotetext{
${ }^{170}$ Ibid. 121.

${ }^{171}$ Ibid. 133-136.

${ }^{172}$ Lawrence, 41.

173 Rooney, 37.
} 
him playing and the way he would play back-up for a fiddle tune. Monroe does not say anything about hearing Shultz play a solo piece, but given the amount of time that Monroe spent with Shultz it is likely that Monroe did at some point hear him play on his own.

Lightfoot concluded that by 1918, five years before Monroe met him, Shultz's technique included four out of the six elements of that define Travis picking: an alternating bass line, accompanying off-beat chord, syncopated melody, and a greatly varied repertoire. Lightfoot also assumes that Shultz's technique included regional "licks," but notes that the final element, the “choking” of chords was added later by Mose Rager. ${ }^{174}$

There are many similarities between Shultz's 1918 solo guitar technique and the ensemble musical texture heard in Monroe's bluegrass. In fact, bluegrass has the same four elements of Travis picking that Shultz's technique had. The guitar and bass player in a bluegrass band play an alternating bass line. There is also a constant "back beat" accompanying chord played by the guitar, mandolin, banjo, or fiddle when backing up a soloist. Bluegrass melodies are also syncopated, contrasting with the regular accompaniment pattern set up by the alternating bass and off-beat chord. The repertoire of a bluegrass band has always been eclectic. Just like Shultz and the Travis pickers, bluegrass musicians are more than willing to take any tune and transform it to fit into their style.

It is possible then that the texture of bluegrass music was influenced by the solo guitar playing of Arnold Shultz. Monroe's statement that, “...[Shultz] used a pick and he could just run from one chord to another..." may be a reference to this playing style . Monroe, "kept it mind" and incorporated the sound into his own music. And while there has, so far, been no research

\footnotetext{
${ }^{174}$ Lightfoot, “A Regional Style,” 132.
} 
done to connect Shultz's solo playing directly with bluegrass, it is possible that this is another debt that Monroe owes to African-American music.

\section{The Monroe Brothers}

At seventeen, Bill Monroe was less concerned with musical influences and more worried about finding employment. He moved away from Rosine to live with his brothers Birch and Charlie in Whiting, Indiana, which is near Chicago.. Like many residents of rural areas in the mid-twenties, Monroe had moved to an urban area to work a job in a factory. He and his brothers worked for the Sinclair Oil Company. ${ }^{175}$

There was not much opportunity to play music in Whiting, but Birch, Charlie, and Bill would occasionally play at small events like house parties. However, new opportunities were becoming available as radio station executives were quickly realizing the value of musical programming. The station WLS Chicago started an old-time music broadcast every Saturday night named "Barndance." By the early thirties the Monroe brothers saw an opportunity to get their music to pay off. WLS had a traveling road show which they sent out to their listening area to advertise, and the brothers were hired for the show. This was Bill's first exposure to the life of a full time traveling musician. He preferred this life to the one he had working at the oil refinery in Whiting. ${ }^{176}$

Monroe played mandolin in the band. Interestingly though, he told Rooney that he had originally wanted to play the fiddle or guitar because those were the instruments that Arnold Shultz and his Uncle Pen had played. Monroe took up the mandolin only as a last choice. His

\footnotetext{
${ }^{175}$ Rooney, 39.

${ }^{176}$ Ibid.,39-40.
} 
brothers wanted to play the guitar and fiddle and he, being the smallest, took up the instrument. Stuck with the mandolin, he decided to play the it in, "a style of [his] own..."177

The mandolin was brought here by Italian immigrants and touring concert musicians. By the 1900s the instrument had become incredibly popular among the urban middle class. There were entire mandolin orchestras in the North that played popular and semi-classical repertoire. The mandolin made its way into the South through a variety of ways but most often through mail order catalogues. Gibson's F5 model, which Monroe himself played, gave the instrument enough resonance to hold its own in southern string bands. Though it was present in string bands before, the instrument did not have a solo and lead role in country music until the 1930s. ${ }^{178}$

The instrument's role changed because Monroe revolutionized mandolin technique. His style drew on his love for the old-time fiddle music that his Uncle Pen had played. There is also a touch of the blues in his playing, and Monroe told Rooney that it was always his intention to, “...really get on a mandolin and play the old-time notes that's in a fiddle number..." ${ }^{179}$ Monroe adapted fiddle techniques and tunes to create his style of mandolin playing.

In 1934, the Texas Crystal company approached Charlie about becoming a solo performer for their radio program on KFNF in Shenandoah, Iowa. Charlie did not want to take the job on his own and asked Bill and Birch to join him. Birch had taken a full time job at a refinery and decided to leave the band. Charlie and Bill became the Monroe brothers, a hillbilly duo.

After only ninety days in Shenandoah, the two brothers were transferred to the larger WAAW in Omaha. The brothers stayed at this station for six months. In 1935 the brothers were

\footnotetext{
${ }^{177}$ Ibid. 41.

${ }^{178}$ Malone, 27.

${ }^{179}$ Rooney, 41.
} 
sent to Columbia, South Carolina and began broadcasting on WIS. The rest of their time together was spent in the Carolinas and Georgia. They also played for radio stations south and east of the southern Appalachians.

Texas Crystals eventually cancelled their radio program, and the brothers went to their competitor's show, “Crazy Water Crystals Barn Dance.” This broadcast featured hillbilly acts like the Blue Sky Boys, Mainer's Mountaineers and Fisher Hendley. The Crazy Water-Crystals program was directly responsible for spreading the Monroe Brother's sound throughout the South. The Monroe Brothers were heard on at least four major radio stations at the time: WBT in Charlotte, WGST in Atlanta, WFBC in Greenville, and WPTF in Raleigh.

Their popularity live and over the radio eventually led to the brothers' first record deal. On February 17, 1936 the brothers recorded their first record in Charlotte, North Carolina. The brothers would go on to record every five to six months for the next two years, and by their last session in January 1938, they had produced sixty songs. All of the records sold well, but their most popular album was the original one from 1936. It featured the songs "What Would You Give in Exchange" and "This World is Not My Home."

In 1938 the brothers had a falling-out that led to their breakup. The details of this parting of ways became the stuff of legend in the country music business. Reasons for the argument vary from money, their wives, or a song. In any case, both brothers were ready to be on their own. Bill Monroe had been playing a secondary role to Charlie for years and was more than ready to branch out. His path would lead him to the Grand Ole Opry and the music that would eventually become bluegrass. ${ }^{180}$

\footnotetext{
${ }^{180}$ Rosenberg, 31-36.
} 
Though many brother duets existed in the South at the time, the music of the Monroe Brothers stood out. They sang higher and played faster. The snappy bass lines of Charlie's guitar style and Monroe's fast and dexterous mandolin playing attracted fans and made their music unique. ${ }^{181}$ The speed, "lonesome qualities," and the hint of the blues, set them apart from the other string bands. ${ }^{182}$

Despite its novel qualities, the music that Bill played with Charlie was not yet bluegrass. Bill and his brother were after two very different sounds. Bill wanted a band with a bigger sound that combined the fiddle, mandolin, guitar, and bass. He also wanted the music to have a stronger beat than what he was playing with Charlie, and he wanted it to be more syncopated, like the blues. $^{183}$

\section{The Blue Grass Boys}

After the split, both brothers formed new bands. Charlie had an easier time of it because he had done all of the lead singing and therefore could more easily find a replacement for his brother. Bill, on the other hand, had to find a guitarist as well as a lead singer and then teach them his songs. Cleo Davis was the first person to join Monroe's new band.

Davis responded to an ad that Monroe had placed in the Atlanta Journal. The Georgia native had grown up listening to the Monroe brothers but had no idea who he was playing for when he auditioned. He ended up playing two well known Monroe Brothers tunes: "This World is not My Home" and "What Would you Give in Exchange for Your Soul" (on a guitar he had just purchased for $\$ 2.40$ at a pawn shop) and landed the gig. After his successful audition,

\footnotetext{
${ }^{181}$ Ibid., 34.

${ }^{182}$ Rooney, 41.

${ }^{183}$ Ibid., 43.
} 
Monroe bought him a new guitar and a new suit to wear for their performances. For the next two months, the pair spent two and a half hours every day in rehearsal. In an attempt to recreate the Monroe Brother's sound, Monroe taught Davis everything he knew about playing the guitar. The pair began auditioning for gigs after Christmas of 1938, and after several rejections, the two finally landed a job at WWNC out of Asheville, NC. They played for a radio program called "Mountain Music Time."

While working this gig, Monroe and Davis expanded their repertoire beyond the songs that the Monroe brothers had played and also added new musicians. The first new musicians added to the group were fiddler Art Wooten and the spoons, bones, and jug player (as well as blackface comedian) Tommy Millard. With these new members in the band, Monroe started to use the name Bill Monroe and his Blue Grass Boys. He chose the name because he was from Kentucky which was nicknamed the Blue Grass State. The band also started making personal appearances for audiences in the region. The initial crowds were small, ranging from fifty to seventy people.

After three months in Asheville, Monroe and the band left for Greenville, South Carolina and acquired the bass player Amos Garen. The string bass was not a normal member of the oldtime string band and was only used by a few groups in the 1930s. The instrument (as well as the man playing it) provided a more solid rhythmic foundation for the band and came to define the sound of Monroe's new music.

Rehearsing in an unused shed of a local gas station, those days in Greenville were critical to the development of the ensemble's sound, as well as to the musicianship of Monroe himself. He and the band worked on solos, duets, fiddle numbers, and vocal quartet arrangements of 
gospel songs. Bill also worked on his own solo songs and gained competency as a lead singer.

He also coached the members of his band to play the music he was hearing in his head. ${ }^{184}$

These new band-mates added variety to Monroe's sound, and, as Cantwell noted, their membership in the Blue Grass Boys demonstrated Monroe's thinking about his music. Art Wooten's fiddle playing connected the band to Monroe's memories of Uncle Pen and old-time music. Tommy Millard ${ }^{185}$ in particular showed his awareness of his music's African-American roots. Though his appearance in the band was brief, Millard was a link to the minstrel show that, despite its racists and stereotypical elements, was itself a link to rural black music which Monroe had experienced as a boy. ${ }^{186}$

The vocal quartet arrangements also required a great deal of rehearsal and coaching. The idea to sing these numbers came from Bill's own childhood experiences in church, an experience that most of the members of the band also had. His arrangements were also influenced by the contemporary gospel vocal harmony style. The popularity of these vocal quartets reached across racial divides. There were white and black quartets and both were popular with people of all colors. Groups like the black Golden Gate Jubilee Quartet (which would later drop "Jubilee” from their name), for example, were popular in the Carolinas and influenced musicians throughout the region. Although the Monroe Brothers had sung religious songs, Monroe's quartet arrangements were a new style for him and were heavily influenced by these black and white quartets. ${ }^{187}$

\footnotetext{
${ }^{184}$ Rosenberg, 42-43.

${ }^{185}$ Monroe identified this man as John Miller to Rooney but it was confirmed by Cleo Davis and Carl Sauceman to be Tommy Millard. cf. Rosenberg.

${ }^{186}$ Cantwell, 78.

${ }^{187}$ Rosenberg, 43-44.
} 
The early Blue Grass Boys were playing for small crowds and broadcasting on a small radio station. Monroe felt the desire to move the band to the center of country music, Nashville, Tennessee. ${ }^{188}$ All of Monroe's preparation and coaching would eventually guarantee the Blue Grass Boys a spot at the Grand Ole Opry.

\section{The Grand Ole Opry}

The program that would become known as the Grand Ole Opry began at WSM in Nashville, Tennessee in 1925. This program was modeled after the National Barn Dance program out of WLS in Chicago. George D. Hay, the announcer for the Barn Dance, realized the popularity of the program's old-time music and brought the idea with him when he began working at WSM in 1925. Two years later the program was named "The Grand Ole Opry" and began to change under the direction of Hay. By the late thirties it had gone from a radio broadcast featuring local amateur acts to a live stage show staffed by professionals and featuring a mixture of music and comedy.

The type of acts that were popular at the Opry before Monroe and his band auditioned in 1939 were singing stars like Roy Acuff and the Delmore Brothers and fiddlers like Arthur Smith and Clayton McMichen. Even as commercial country music began to show the influence of Hollywood and jazz, Hay insisted that the Opry stay true to its rural roots. In the forties he fought to keep drums off of the Opry stage and consistently discouraged the use of electric instruments. Hay's goal was to preserve what he saw as the authenticity of country music.

While they disagree on the other numbers, Bill Monroe and Cleo Davis agreed that they played "Mule Skinner Blues" for their successful Opry audition. The song was a version of a

\footnotetext{
${ }^{188}$ Ibid., 45.
} 
blue yodel originally done by Jimmy Rodgers. The Blue Grass Boys version was wholly new; they played "Mule Skinner Blues" at a faster tempo, in a higher key, and gave it what Monroe called the "bluegrass beat." The song was the first to be cited by Monroe as a departure from the sound of the Monroe Brothers.

The combination of old-time flavor and professional musicianship heard in "Mule Skinner Blues" was perfect for Hay's Opry. According to Monroe, it was the first song ever to receive an encore at the Opry upon its premiere. Cleo Davis recalled how it stunned the other performers who were watching in the wings. While there is no contemporary account of the night the song premiered, both Monroe and Davis agree that the band's sound was heard as unique and original by their fellow performers. ${ }^{189}$

The original Blue Grass boys were well received at the Opry. By 1940 they were being asked to make an ever increasing number of personal appearances. The broadcast range of the Opry meant that these road shows were scheduled all over the southeast in Alabama, Kentucky, West Virginia, and the Carolinas. ${ }^{190}$

The year 1940 also saw the first personnel changes in the band. By the time Blue Grass Boys made their first recordings for RCA Victor in October of that year, the band consisted of Monroe, Clyde Moody on guitar, Willie Egbert Wesbrook on bass, Tommy Magness on fiddle. The band recorded eight songs, and the session was the last that the Victor company would make before World War II. ${ }^{191}$

The first tracks they recorded at the session were Monroe's version of "Mule Skinner Blues," followed by two duets, a gospel quartet, Moody's version of "Six White Horses," and

\footnotetext{
${ }^{189}$ Ibid., 45-47.

${ }^{190}$ Ibid., 51.

${ }^{191}$ Ibid., 54.
} 
another Monroe solo, "Dog House Blues.” They also recorded two instrumental tunes: Monroe's “Tennessee Blues” and Magness's “Katy Hill.", ${ }^{192}$ Monroe's RCA Victor records of 1940 and 1941 display certain eccentric elements which prefigure bluegrass music which would arise five years later. As discussed below, these elements are mostly rhythmic and display the influence of the blues. ${ }^{193}$ Of the eight songs on the album, "Mule Skinner Blues" and "Katy Hill” stand out as the most like bluegrass.

"Muleskinner Blues" is the most rhythmically complex piece on Monroe's 1940 and '41 Victor recordings. The song is actually a version of Rodger's "Blue Yodel No. 8." Cantwell insists that the tempo "rolls, not drives." Monroe plays guitar on the recording, and it is the only recording of him doing so. He claimed that he could not find a guitarist who could play the rhythm he heard for the song. According to Cantwell, the sound that Monroe was trying to capture, "was a layered polyrhythm, with accentual strata constantly shifting against one another, such as we normally hear in traditional jazz." 194

Also on these RCA Victor recordings is "Katy Hill," composed and played by fiddler Tommy Magness. Magness's old-time shuffling fiddle is pushed to an extremely fast pace by Monroe and the rest of the band. The band also yells things like, "Swing your partner!" and "Promenade!" referencing the piece's original role as a dance tune. It would be extremely difficult to dance to the band's tempo, and instead "Katy Hill" is a representation of an old-time dance.

The October 1940 recording hints at bluegrass. The tracks cover a variety of genres including hoedowns, fiddle tunes, gospel songs, sentimental or "heart" songs, blues, and a

\footnotetext{
${ }^{192}$ Ibid., 52.

${ }^{193}$ Cantwell, 82.

${ }^{194}$ Ibid., 85.
} 
traditional dirge. The band embraced these contrasts in repertoire, and later these different genres would be unified in bluegrass's single sound.

At this point though, Monroe does not fully create the sound he intended. The guitar and mandolin are not suited to create the accents required to accomplish this, and the fiddle part also accents the down beat of every other measure, further obscuring Monroe's intended rhythmic pattern. There is also no constant back beat, which characterizes bluegrass. ${ }^{195}$

\section{The Blue Grass Boys During the War}

These first recordings were released during the Second World War. The war affected the country music industry in many different ways. Because of a wartime shortage of shellac and disputes between the musicians' union and the record companies, the major labels produced very little until 1945. Band personnel, like Blue Grass Boy Pete Pyle, were drafted for military service. Pyle was replaced by former band member Clyde Moody who would remain with the band for three more years. ${ }^{196}$ Despite the lack of recordings, hillbilly music flourished during the war. Many rural people had migrated to the cities for war time jobs. For these new city dwellers, the hillbilly music played on radio programs were a reminder of home. ${ }^{197}$

Instead of recording, Monroe spent the war years touring with the Opry's traveling tent show. The tent show was actually one of the last minstrel shows and featured music, comedy, and a blackface duo named Jamup and Honey. By the summer of 1943, Monroe had his own traveling tent show. It is important to note that Monroe was putting on a show, not a concert. The traveling tent show had its roots in medicine shows, minstrel shows, traveling repertory theatre,

\footnotetext{
${ }^{195}$ Ibid., 85-86.

${ }^{196}$ Rosenberg, 55.

${ }^{197}$ Ibid.,61.
} 
fiddler's conventions, and other entertainments that were popular throughout the South before radio was widespread. The tent show essentially fused all of these earlier entertainments together into a single presentation. Monroe's show was so popular that even though gasoline was rationed during the war, the tent show was incredibly well attended and audience members would travel for miles just to get there.

Though being one of Monroe's Blue Grass Boys was not financially lucrative, musicians yearned to play in his band. Playing with an exacting musician like Monroe provided valuable experience, and being a Blue Grass Boy at the Opry also ensured a great deal of publicity. These reasons, along with the vagaries of the music business and the uncertainty of wartime, ensured a great deal of turnover in Monroe's band.

Howdy Forrester joined the band in 1942 as a fiddle player. Forrester was born in Tennessee and played fiddle in the Texas style. Monroe appreciated his stylistic versatility and his ability to play in keys outside of the range of most old time fiddlers. The standard that Forrester set while he was with Monroe stood as an example for all bluegrass fiddlers that followed him.

Monroe added the first banjo player to his band for these tent shows. David Akeman, also known as "Stringbean," played claw-hammer style banjo and was also a comedian. Forrester left the band in 1942 to join the Navy. His fiddling was replaced by the co-composer of "Orange Blossom Special," Robert Russell "Chubby" Wise. After an unsolicited backstage audition, Wise was hired on a trial basis. Monroe wanted to be sure that Wise would adapt his western swing influenced fiddle playing to the band's sound.

The band at the Columbia session in 1945 included Monroe, Chubby Wise on fiddle, an accordionist “Sally Ann” (actually Wilene Forrester), Tex Willis on guitar (replacing Clyde 
Moody) and "Cedric Rainwater" (who was actually Howard Watts and who had replaced Wilie Wesbrooks on bass). The record had four Monroe vocal features including "Kentucky Waltz," "Rocky Road Blues," and "Footprints in the Snow." There was one vocal duet, "True Life Blues," which also featured the first recording Blue Grass Boys banjo break, played by Stringbean. There were two trios and a purely instrumental track called "Blue Grass Special." This instrumental was a blues in the key of A, and everyone in the band played a solo. These solos alternated between players, like they do in a jazz band. Like jazz, it showcased the personalities of the different members of the band but also required the band to play as an ensemble. ${ }^{198}$

Despite these significant developments, the band that Monroe had between the years 1941 and 1945 was a typical hillbilly ensemble. The sound is richer and fuller than the previous Blue Grass boys but is also more uniform and homogenous than what we now think of as bluegrass. As Cantwell noted, it lacked, "the rough textures of the old dance bands [and] the intricate design, the fire, [and] the brilliance of bluegrass." ${ }^{199}$ The sound of the individual instruments is buried in the texture of the band and the only thing in the foreground of the music is Monroe's lead singing.

Monroe's band was basically a hillbilly band with a star singer, not unlike the other country music groups of the period. Despite the quality and uniqueness of Monroe's band, country fans did not consider his music to constitute a new style. For them the Blue Grass Boys were a great band that played at high speed, but the songs were considered still be within the genre of popular music. ${ }^{200}$

\footnotetext{
${ }^{198}$ Ibid. 55-63.

${ }^{199}$ Cantwell, 87.

${ }^{200}$ Rosenberg, 61.
} 
Monroe's music was close to breaking away from the hillbilly sound, but certain developments needed to occur before bluegrass could emerge. First, the Blue Grass Boys required the right personnel, musicians who could help Monroe fully realize the sound he had been striving to achieve. Second, some musical element was needed that would tie all of Monroe's ideas into a rhythmic framework. The thing that would do this, and thus create the style of bluegrass music, was the three-finger banjo picking of Earl Scruggs.

\section{The Band That Made Bluegrass}

During the postwar years, Monroe's Blue Grass Boys band played as far west as Oklahoma and as far north as Ontario, Canada. His records were popular on jukeboxes and sold well in record stores. His songs were beginning to be covered by other country musicians including Pee Wee King and his Golden West Cowboys and Bradley Kincaid. The band that Monroe had during these years is considered his best. ${ }^{201}$ This band is the one that would create bluegrass: Bill Monroe, Chubby Wise, Cedric Rainwater, Lester Flatt, and Earl Scruggs. ${ }^{202}$

Chubby Wise had been playing with the band before 1945 and continued to meet the high bluegrass fiddling standards previously established by Wooten, Magness, and Forrester. Wise, though, had a distinct style of melodic interpretation and a smoothness and tone that surpassed most other fiddlers. He is also known for his jazzy fiddle breaks. ${ }^{203}$

Cedric Rainwater played with Monroe's band periodically during the postwar years and participated in the first true bluegrass recordings of 1946 and 1947. He sometimes sang baritone

\footnotetext{
${ }^{201}$ Ibid., 68.

${ }^{202}$ Ibid., 71.

${ }^{203}$ Ibid., 70.
} 
and bass but is remembered most for his upright bass style. This sound gave bluegrass its fourbeat foundation. ${ }^{204}$ Rainwater also helps contribute to the pulse with his walking bass line. ${ }^{205}$

Lester Flatt joined the Blue Grass Boys sometime between February and April of 1945. The guitarist, from Sparta, Tennessee, was one year younger than Monroe and had previously played with Clyde Moody and with Monroe's brother Charlie. Flatt's guitar style, which involved the use of a thumb and finger pick to play the bass note and brush the chord, was similar to that of Moody and Charlie Monroe. His style though was more syncopated and used more bass runs than these other two. One such run, "The Lester Flatt G run" is heard on virtually every bluegrass recording. The run was actually a variation of another ascending guitar run that was common in American popular music. In fact, it can be heard on the earlier recordings of Charlie and Bill Monroe.

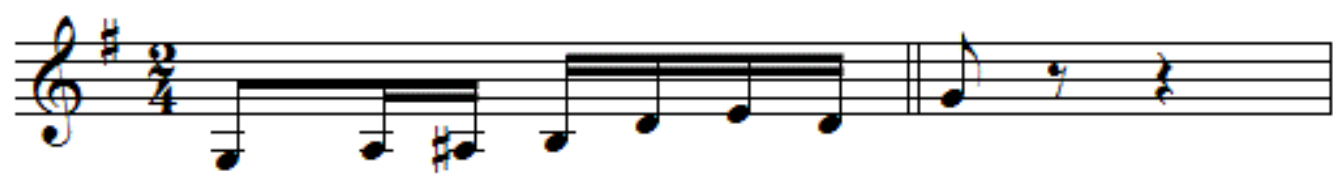

Ex. 3.1 The Lester Flatt G run.

Flatt also sang lead in the band. His mellow tone blended well with Monroe's sharp tenor. With Flatt singing lead, Monroe's conception of bluegrass tenor harmony lines began to develop. Rather than singing a line that paralleled the lead he began to create lines that were more like countermelodies. There were often unexpected leaps and unusual intervals formed with the lead part.

In September 1945 Stringbean left Monroe's band and was not immediately replaced. In fact, members like Lester Flatt were resistant to having a new banjo player in the band. He felt

\footnotetext{
${ }^{204}$ Ibid., 69.

${ }^{205}$ Cantwell, 106.
} 
that Stringbean's old fashioned banjo style could not keep pace with the band's fast tempos, and he thought that another banjo player would only hold the band back.

Earl Scruggs, from Flint Hill, North Carolina was twenty-one years old when he auditioned for the Blue Grass Boys. He played two tunes, "Sally Goodin," an old fiddle tune that Scruggs thought Monroe could relate to, and "Dear old Dixie" a song that he was sure Monroe had never heard played on the banjo. Flatt was stunned at what he heard. Scruggs was doing things on the banjo that were fresh and unique, and when Monroe asked Flatt what he thought of the banjo player, the guitarist insisted that he be hired. Monroe agreed and Scruggs played on their next Opry appearance.

Monroe liked the sound of the five-string banjo and thought that Scruggs could play with the band in the same way that Stringbean had. However, one of the important things that Scruggs's three-finger technique did was to make the banjo a versatile and flexible lead instrument. Scruggs took solos on a variety of songs including slow waltzes, blues, medium tempo duets, and fast instrumental breakdowns.

It was with this band that the bluegrass would emerge. Long-time listeners of the band began to notice a significant change in Monroe's sound in 1945. This change can be heard in the twenty-eight recordings that this incarnation of the Blue Grass Boys recorded in 1946 and $1947 . .^{206}$

\section{Scruggs Banjo Roll and Bluegrass Music}

There is some debate about which of these twenty-eight songs is the first true bluegrass song. According to Pete Kuykendall, the first recordings to bear all of the elements of bluegrass

\footnotetext{
${ }^{206}$ Rosenberg, 68-76.
} 
music were "Will You Be Loving Another Man," and "Blue Yodel no. 4" (another Jimmie Rodgers song) recorded for Columbia on September 16, 1946. ${ }^{207}$ Cantwell, however identifies "Will You be Loving Another Man" as the first recording to display all of the elements of bluegrass. $^{208}$

Cantwell elaborately described the new bluegrass sound heard in the song:

Here the hounds of syncopation - an emphatic back beat and a driving, unflagging banjo roll- have been let loose, flushing the rhythm out of the meter and opening a wide antiphonal frontier behind the lead where Monroe's parallel harmony lines become, by a kind of rhythm refraction, improvised countermelodies playing around the beat and welling up between lead phrases in patterns built on the call-and-response plan of AfroAmerican music. ${ }^{209}$

The rhythm seems to float like in a jazz recording. The players drive it forward and fill in the spaces with licks and runs. This rhythmic framework sets up the classic bluegrass recordings of October 1947. The banjo roll also serves to hold together the two rhythmic forces in bluegrass: the pulse and the backbeat. ${ }^{210}$

Scruggs's banjo style is the first instrumental technique exclusive to bluegrass. Cantwell calls it a microcosm of bluegrass music. The simple but effective style echoes all of the musical influences that came to define bluegrass. In fact, bluegrass could not evolve until the technique was integrated into Monroe's band. ${ }^{211}$

According to Cantwell, the style of Monroe's original band, “...was already congested with accents and with the rhythms those accents redundantly reinforced..."212 Scruggs's roll broke up this congestion and helped define the rhythmic roles of the instruments in bluegrass.

${ }^{207}$ Pete Kuykendall "Bill Monroe and his Bluegrass Boys,” Disc Collector, no. 13 (no date): 19 ref. in Cantwell, 328.

${ }^{208}$ Cantwell, 106.

209 Ibid.

${ }^{210}$ Ibid. 106-108.

211 Ibid. 113.

${ }^{212}$ Ibid. 100. 
The bass plays every beat without accent, the mandolin and plays the offbeat, the guitar plays a combination of the two, and the banjo plays the subdivision of each beat.

The Scruggs's roll divides the beat into two parts making the old time $2 / 4$ string band meter into the $4 / 4$ meter of bluegrass. This new meter allowed Bill Monroe to insert his preference for the black-inspired back beat. Scruggs's style is imitated in different ways by different bluegrass players, but it always consists of a chain of sixteenth notes in $4 / 4$ time played by the thumb, index, and middle fingers. The anatomy of the style consists of different arpeggiated rolls which group into patterns of three sixteenth notes each. ${ }^{213}$

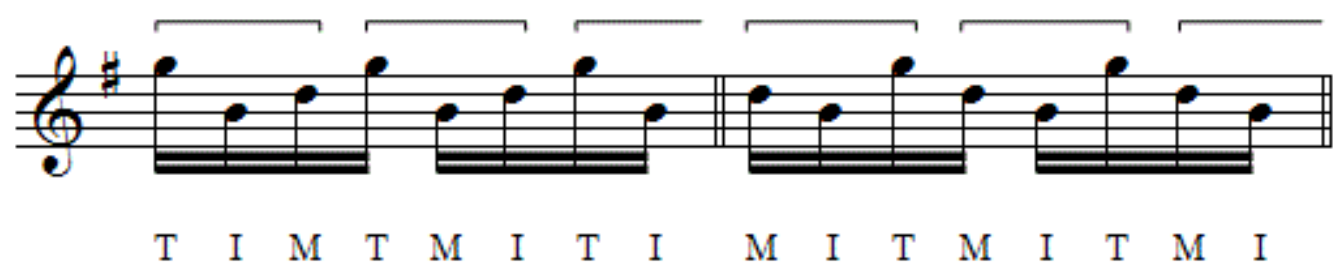

Ex. 3.2 Two Scruggs banjo rolls: the forward roll (left) and the backward roll (right). The letters indicate the finger used to play each note with the right hand. $\mathrm{T}$ is thumb, I is index, $\mathrm{M}$ is middle. The brackets indicate the groups of three sixteenth notes to which Cantwell refers.

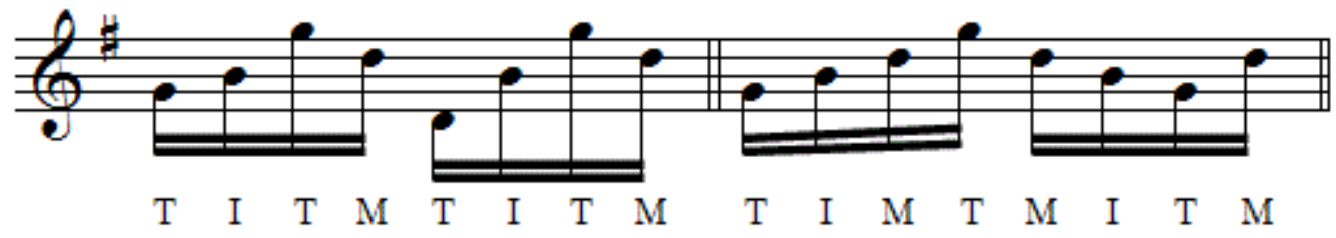

Ex. 3.3 Two more Scruggs banjo rolls: the alternating thumb roll (left) and the reverse roll (right). See Ex. 3.2 for an explanation of the right hand fingering.

The earliest foundations of the style were laid by Charlie Poole who played the banjo in the influential old-time band, The North Carolina Ramblers, active from 1917 to 1930 . At the

${ }^{213}$ Ibid, 100-105. 
center of the Ramblers' tightly interwoven sound was the driving three-finger style of Poole. He adapted his style from the phonograph recordings of "classic" banjoists.

Classic banjo is a style of banjo playing that developed in the 1860 s. Sometimes called "guitar style," this technique involves picking the individual strings of the banjo with the fingers of the right hand. The minstrel style of banjo playing, which in the mid-nineteenth century was by far the most common, was a stroke style which used the entire hand to play multiple strings at once. Classic banjo remained popular among the urban upper class until the beginning of the twentieth century.

Classic banjoists did not simply play arrangements of classical music on the banjo. In fact, this finger-picking style was used to play music as varied as popular songs, folk tunes, classical pieces, and ragtime. Banjo virtuoso Vess Ossman (1868-1923) played all of these styles but was best known for his ragtime tunes. He made thousands recordings during his career and influenced later banjo players such as Fred Van Eps $(1878-1970) .^{214}$

Charlie Poole developed his style of banjo finger-picking by listening to recordings of Ossman and Van Eps. Poole's style combined their rapid finger picking technique with the oldtime and hillbilly music of his region of North Carolina. This development marked the beginning of a transformation in banjo playing that would result in the instrument taking a leading role in country music and no longer functioning as only a back-up instrument. ${ }^{215}$

Poole and the North Carolina Ramblers had a lasting influence on the string bands of north-central North Carolina and south-central Virginia. The recordings of these other string bands from 1926-1931 show this influence. After World War II, the Rambler's recordings went

\footnotetext{
${ }^{214}$ Robert B. Winans and Elias J. Kaufman, "Minstrel and Classic Banjo: American and English Connections," American Music, 12, no.1 (Spring 1994), pp. 1-30.

${ }^{215}$ Patrick Huber, Lint Head Stomp: The Creation of Country Music in the Piedmont (Chapel Hill: The University of North Carolina Press, 2008), 108.
} 
on to influence folk revival artists and bluegrass pioneers. Poole's banjo playing was imitated by Snuffy Jenkins, Earl Scruggs, Don Reno, and Ralph Stanley, and is widely considered the forerunner to modern bluegrass banjo. ${ }^{216}$ Poole's recordings of "White House Blues" and "Don't Let Your Deal Go Down” have, what Cantwell called, “...a distinctly bluegrass flavor,” and these songs entered the bluegrass repertoire from Poole's recordings. ${ }^{217}$

These later banjo players took Poole's technique further and had a strong influence on Scruggs and other bluegrass banjo players. Snuffy Jenkins (1908-1990) is known to have used the three-finger style to play fiddle tunes and slow numbers on the banjo. There were also lesserknown three-finger pickers active in the thirties and early forties: Hoke Jenkins, Jonny Whishnant, and Wiley Birchfield, now considered the prototypical three-finger banjo players. ${ }^{218}$

Earl Scruggs was born on January 6, 1924, in the Flint Hill community in North Carolina. Banjo players and banjo techniques thrive in this part of North Carolina, and Scruggs was exposed to the three-finger style through his father and his brother. He was also familiar with banjo players from western North Carolina like Mack Woolbright, Rex Brooks, Smith Hammett, and Snuffy Jenkins. Though it is clear that Scruggs did not originate the banjo style, he did perfect it and popularize it. ${ }^{219}$

Allen Farmelo noted that while the banjo itself is universally identified as African in origin, the bluegrass style of playing it is erroneously identified as a solely white innovation. ${ }^{220}$ Conway also made note of bluegrass banjo techniques that developed from a synthesis of white and black banjo playing. The black-white musical exchanges in the upper South that led to the

\footnotetext{
${ }^{216}$ Ibid., 159.

${ }^{217}$ Cantwell, 105.

${ }^{218}$ Rosenberg, 71 .

${ }^{219}$ Malone, 327.

${ }^{220}$ Farmelo, 193.
} 
mountain string band and old time music also led to the development of bluegrass music in the $1940 s^{221}$ Specific banjo picking techniques, now standard in bluegrass music, come from the black banjo folk tradition. "Complementing" is an up-picking technique that uses the thumb to play a note on a string other than the drone string. ${ }^{222}$

Cantwell also compared the black derived claw-hammer technique and bluegrass playing. Both styles require the constant ringing of the banjo's drone string. While the addition of the drone string to the instrument is traditionally attributed to the minstrel Joel Walker Sweeney, it is most likely that the drone string was present on the African ancestors of the banjo, or possibly added by blacks in the Americas. The string does not really drone in the low register the way a bagpipe does, but rather chimes rather high in pitch, like a bell or gong in African music.

Scruggs's style is also linked to African music through the ragtime banjo style of the minstrel stage. Gilbert Chase argued that ragtime developed from late nineteenth century "coon" songs which were an outgrowth of the minstrel tradition. In the 1870 s and 1880s blacks were often involved in minstrelsy as virtuosic banjo players. The fact that the first ragtime piano piece, J.S. Putnam's "New Coon in Town," is subtitled a "Banjo Imitation" suggests that banjo ragtime developed before other forms of ragtime. Ragtime banjo entered Appalachia through the minstrel show, and once there, string band ragtime became its own style separate from minstrelsy. Banjo players like Charlie Poole and Fred Van Epps both played ragtime banjo and both used a threefinger style. Scruggs himself was a ragtime banjo expert and many ragtime "licks" became associated with bluegrass banjo style. ${ }^{223}$

\footnotetext{
${ }^{221}$ Conway, “African Banjo Echoes of Appalachia,” 62.

222 Ibid. 202.

${ }^{223}$ Cantwell, 103-104.
} 
Farmelo asserted that Scruggs's three-picking style also has its roots in the three-finger blues guitar styles popular in North Carolina during Scruggs's childhood. Furthermore, Farmelo identified several three-finger banjo pickers who predate Scruggs including Gus Cannon, who was active between 1914 and 1929, and Hobart Smith born in 1897 in Saltville, Virginia, near the Sugar Grove Region. Smith was influenced by blues guitar players, black fiddlers, and black banjo players. ${ }^{224}$

Just like the mountain string band, old-time music, hillbilly, and bluegrass music itself, Scruggs-style banjo developed from a variety of black and white predecessors. Ragtime, the blues, classical banjo, as well as other black and white styles are all heard in bluegrass banjo technique. As Conway put it, bluegrass playing, “...reflects its African-American and CelticAmerican roots. ${ }^{, 225}$ Scruggs's banjo playing is what came to define the music; the core of the bluegrass style is as much black as it is white.

\section{Bluegrass Becomes a Style: Flatt and Scruggs and the Stanley Brothers}

The beginning of 1948 saw the last shows that Flatt, Scruggs, Wise, and Rainwater would play with Monroe. One these last appearances happened in Huntington, West Virginia on January $25^{\text {th }}$. Billboard wrote that the show, which also featured Al Rodgers, Bradley Kincaid, and the Blue Grass Quartet, was the largest folk show to ever come to the town.

Chubby Wise was the first to leave. He moved to take a job at a radio station in Arlington, Virginia along with Clyde Moody. Flatt and Scruggs were the next to give their notice to Monroe. While there is no contemporary account of the reasons for their departure, the event is extremely

\footnotetext{
${ }^{224}$ Farmelo, 193-194.

${ }^{225}$ Conway, "African Banjo Echoes of Appalachia," 289.
} 
important to the development of bluegrass music. In later interviews, Monroe looked at their leaving the band as normal band turnover, still according to Rosenberg, his actions at the time and in the years to follow, "...made it clear that he was angered by their leaving."

The first account of the split appeared in 1968 in Scruggs's technique book Earl Scruggs and the Five-String Banjo. There he stated that he had decided to quit because he was tired of the constant grueling travel required of him in Monroe's band. According to Scruggs, he wanted to return home, get a job (musical or not), and care for his aging mother. In a 1971 interview, Flatt echoed Scruggs's story and added that the pair had not coordinated their departure. Speicifically he insists that he had decided to quit before he knew of Scruggs's plans.

Jake Lambert, a longtime friend and biographer of Flatt, provided a different account. Lambert tells us that Flatt and Scruggs had both realized that there was not much money to be made as sidemen to Monroe. During a Christmas break from the band, Flatt, Scruggs, and Rainwater got together and decided to leave and form their own group. ${ }^{226}$

While Monroe was used to regular turnover in this band, this mass exodus infuriated him. He assumed (perhaps correctly) that the whole thing had been planned. Left with only his new fiddler, Monroe's first step was to refill the ranks of his band. He chose Don Reno on banjo, Jackie Phelps on guitar, ad Joel Price on bass. ${ }^{227}$

The new Blue Grass Boys were in action for only a month before Flatt, Scruggs, and Rainwater began their new gig at a radio station in Danville, Virginia. By May of 1948, Flatt and Scruggs had formed the Foggy Mountain Boys and were joined by Jim Shumate, Cedric

\footnotetext{
${ }^{226}$ Jake Lambert with Curly Sechler, Biography of Lester Flatt: "The Good Things Outweigh the Bad." (Hendersonville, Tennessee: Jay-Lyn Publications, 1982), 7-8, quoted in Rosenberg, 79.

${ }^{227}$ Rosenberg, 78-80.
} 
Rainwater, and Mac Wiseman. Their band would eventually become one of the most popular country acts in the nation. ${ }^{228}$

The recordings the Foggy Mountain Boys made for Mercury from 1948 to 1950 established a body of work that would remain in the repertoires of every bluegrass band that followed them. The songs they cut included "My Little Girl in Tennessee," "Foggy Mountain Breakdown," "My Cabin in Caroline," "We'll Meet Again, Sweetheart," “Old Salty Dog Blues," and "Roll in My Sweet Baby's Arms.",229

The Foggy Mountain boys were also responsible for expanding the standard instrumentation of the bluegrass band. Flatt and Scruggs added a dobro to their band in 1955, and while some purists frowned on its use, the instrument became a part of the bluegrass sound. While their dobro player Josh Graves was certainly not the first country musician to play the instrument, he did much to popularize it among younger musicians. Graves began playing the dobro in an older style which he got from his hero Cliff Carlisle. He quickly became captivated by Scruggs's banjo playing and adapted the three-finger technique to the dobro. The result was a syncopated style that was flexible enough to allow the dobro to play up tempo breakdowns as well as slow songs and ballads. ${ }^{230}$

The dobro came into country music through its appearances in vaudeville acts and traveling tent shows. After Hawaii became a part of the United States, musicians from the islands who played the slack-key guitar began to appear on the mainland. After the first World War,

\footnotetext{
${ }^{228}$ Malone, 330.

${ }^{229}$ Ibid., 332.

${ }^{230}$ Ibid., 333-334.
} 
troupes of these musicians began touring the South, and the whining, crying sounds, which were part of the slack-key tradition and the blues, found a new home on the dobro resonator guitar. ${ }^{231}$

\section{The Stanley Brothers}

WCBY in Bristol, Tennessee was one of the many stations to crop up after the Second World War. It began operating in December of 1946 and had a clear broadcasting frequency that reached the mountain regions of Tennessee, North Carolina, Virginia, West Virginia, and Kentucky. The Stanley Brothers were playing on the station as soon as it began broadcasting.

The two Stanley brothers Carter and Ralph were veterans of the war who had returned and decided to start a country music career. Carter sang lead and played guitar in the vein of Lester Flatt. Ralph played a two-finger banjo style and sang baritone. While they worked out of Bristol, the pair also played with Darrell Lambert, who played mandolin and sang tenor, and fiddler Leslie Keith.

Their band, the Clinch Mountain Boys, imitated at least superficially the sound of Monroe's Blue Grass Boys and became extremely popular in the rural areas encompassed by WCBY's broadcast range. The Stanley Brothers made personal appearances in the region and regularly played for sold-out audiences. They produced records on an independent regional label called Rich-R-Tone which were also in high demand. The first of these featured four songs, "The Girl Behind the Bar," "Mother No Longer Awaits Me at Home," "Death in Only a Dream," and "I Can Tell You the Time." The second featured "Little Glass of Wine" and "Little Maggie," and became the brother's first hit.

${ }^{231}$ Ibid., 26. 
The Stanley Brother's sound began to change when Flatt and Scruggs and the Foggy Mountain Boys arrived in Bristol. The Foggy Mountain Boys embodied what would come to be called the bluegrass sound. This band made quite an impression on the people listening to WCBY and on the Stanley brothers themselves. The pair began to become dissatisfied with the sound of the Clinch Mountain Boys.

The brothers strived to get their band to sound as close to the Blue Grass Boys as possible, and thus as close to the bluegrass style, as they possibly could. Lambert's hero was Bill Monroe, and the mandolin player aimed to imitate his singing and playing. They also replaced their fiddle player with former Blue Grass Boy Art Wooten. Ralph Stanley also changed his banjo style to match the three-finger style of Earl Scruggs. It is unclear whether Ralph Stanley learned the style from Scruggs while they were both at Bristol, or if he learned it directly from Snuffy Jenkins.

The Clinch Mountain Boys also directly borrowed songs from Monroe's band. In fact, the Stanley Brothers' version of "Molly and Tenbrooks" released in 1948 is, "the first direct evidence that the total 'sound' of Monroe's 1946-1948 band was being imitated by other bands. It marks the transition from the sound of Monroe's band to the musical genre [style] known as bluegrass." Monroe himself acknowledged this fact at the first bluegrass festival in 1965.

Flatt and Scruggs and the Stanley Brothers were not the only groups copying Monroe's sound around 1948. In December 1947, the Bailey Brothers added a five-string banjo player named Wiley Birchfield to their band, and in 1948 they recorded six songs that show Monroe's influence. Carl Sauceman and Thomas Martin in Greenville, South Carolina, the Briarhoppers in Charlotte, and the Blue River Boys from Gastonia, North Carolina, were also imitating the sound. It was Flatt, Scruggs, and the Stanley Brothers though, that drew most of the anger from Monroe. Even though he encouraged other bands to cover his music, he hated the copying of his 
sound, and this is exactly what Flatt, Scruggs, and the Stanley Brothers were doing. In the late 1940s Monroe was less concerned with disseminating a musical style and more worried about the financial threat posed by other bands cutting into his market. This, coupled with the sense of betrayal Monroe felt when Flatt and Scruggs left his band, caused him to hold a grudge until the late 1960s. He used his influence to keep Flatt and Scruggs off the Grand Ole Opry stage for several years, and he would never again let any of his band members form teams or gain any fame beyond that of his own. In March of 1949 the Stanley brothers signed with the Columbia label. The move caused Monroe to leave Columbia and sign with Decca records. His main reason for leaving was the fact that the Stanley Brothers had a sound too close to his own. ${ }^{232}$ Despite Monroe's objections, the songs that Flatt, Scruggs, and the Stanleys recorded between 1946 and 1948 established the core bluegrass repertoire and established the bluegrass sound. Through the emulation of others, the bluegrass style was created. The name "bluegrass" however was not being used while all of this was happening. Flatt, Scruggs, the Stanleys, and the other imitators did not think of themselves as playing bluegrass but as playing country music. The idea of bluegrass as a separate style did not emerge until the 1950s. ${ }^{233}$

It is indisputable that the key figures in bluegrass were influenced in various ways by African-American music. Bill Monroe was inspired by the blues and said quite plainly that this black music is in bluegrass. He also looked up to the black musician Arnold Shultz in his childhood, and it is possible that Shultz's guitar playing contributed to Monroe's conception of bluegrass texture. The element that hold bluegrass together, Scruggs-style banjo, developed from

\footnotetext{
${ }^{232}$ Rosenberg, 80-88.

${ }^{233}$ Ibid. 89-90.
} 
a synthesis of white classical and minstrel banjo playing and black ragtime banjo and guitar finger picking techniques.

It is a shame then that the true roots of bluegrass music are currently obscured in the minds of the average American. The banjo, in particular, is often thought of as an instrument invented by and played only by white, racist, hillbillies. People who hold this conception would be shocked to learn that the instrument is originally from Africa and that its invention occurred only because of contact and cooperation between blacks and whites. These same people might also be shocked to learn that bluegrass music, also associated exclusively with whites, was created in the same way. 


\section{CHAPTER 4}

\section{CONCLUSIONS}

The unique style of country music called bluegrass was conceived of by Bill Monroe, refined by the banjo playing of Earl Scruggs, and proliferated by Scruggs, Lester Flatt, and the Stanley Brothers. As we have seen though, the style was not single-handedly created by these men. It owes all that it is to the music and musicians, both white and black, that came before it.

The origins of the instruments in bluegrass band reflect these black and white roots as well that of other cultures. The European fiddle and the African banjo were first played together by blacks and whites throughout the frontier South and the Appalachians. The guitar was added to the pair by black blues musicians migrating to the mountains. The string bass, also from Europe, filled out the sound of the bluegrass band. The mandolin and the dobro were added later and the typical bluegrass ensemble was complete. The vocal style of bluegrass developed from Southern church music, mountain ballad singing, gospel quartets, field hollers and the blues. Thus bluegrass singing shows the influence of blacks and whites as well.

The melodic and rhythmic characteristics of bluegrass are descended from the British ballad tradition that survived in the Appalachian Mountains. These ancient songs were blended with West African rhythmic conceptions and the blues to create the sound of country music and bluegrass. The heterogeneous sound ideal, an African concept, is also found in bluegrass, and the roles of instrumentalists in the bluegrass band are conventionalized just as they are in a jazz band. Improvisation, another legacy from Africa, is also expected of the musicians. 
Bluegrass songs come from a variety of sources and reflect the diversity that bred the style. Bluegrass bands play instrumental pieces such as British reels and hornpipes alongside African-American fiddle breakdowns and banjo tunes. White hymns are sung alongside black spirituals. Blues songs are performed on the same set as Appalachian ballads and folk songs. The old-time genre itself has mixed roots, and the earliest hillbilly stars, who inspired the generation of musicians who created bluegrass, owe a great deal to black musical styles.

As noted above, most people believe that bluegrass music, "is, and has always been the traditional music of white people."234 The racially complex history of the style has been suppressed to the point that the average country music fan would be shocked to learn that black music had any influence on bluegrass. Farmelo offered several explanations for this denial of African influence.

The first is that bluegrass is often thought of as the accomplishment of a single individual, Bill Monroe, in the mistaken belief that he developed the style independently of any other influence and therefore bluegrass music owes nothing to other musical styles. In their bluegrass histories, Neil Rosenberg and Robert Cantwell focus almost exclusively on Monroe and his career, and even Monroe's fellow bluegrass musicians view him with a sort of reverence. Farmelo believed that this simplification of bluegrass history happens because, "we often compress U.S. history into stories about the careers of successful white males, leaving others invisible. ${ }^{, 235} \mathrm{He}$ also noted that the country music industry itself focuses on individuals who rise above the rest: "The tendency to emphasize one person as founder of a musical style exists, partly, because star-making machinery (Nashville, Hollywood, Broadway, TV or, generically,

\footnotetext{
${ }^{234}$ Farmelo, 185.

${ }^{235}$ Ibid., 186.
} 
'the industry') often focuses its attention on one figure at a time." ${ }^{, 236}$ The preference given to Monroe, while undoubtedly deserved, obscures the other individuals who contributed to the bluegrass style, including African Americans.

Farmelo's other "traditional” history of bluegrass contended that all American music, including bluegrass, descends directly from European sources. Some of these narratives, like the one Farmelo cited in his article, go so far as to trace American popular music and bluegrass back to the poetry of the ancient Greeks. ${ }^{237}$ These histories ignore the contributions of African Americans to bluegrass in favor of a purely European lineage. Farmelo explained that documents of this kind "... [are] part of a metanarrative which [grows] out of, and [supports], a somewhat white-supremacist, patriarchal ideology."238

The ethnographic research that Farmelo presented at the end of his article suggests that bluegrass music is "entangled with a cluster of cultural icons which indicate, and have historically indicated, the racism of poor white Southern people. ${ }^{239}$ Through interviews with attendees of bluegrass festivals, Farmelo documented the presence of racist iconography like the Confederate flag, banjo players in blackface, and the Ku Klux Klan. The presence of these elements among some bluegrass fans has all but guaranteed the music's association with the poor, white, hillbilly stereotype. Farmelo concluded that these stereotypical associations contribute to the perception that bluegrass is an exclusively white music. ${ }^{240}$

Whatever the reason, the fact remains that bluegrass is popularly perceived of as a white music. Even Mayne Smith's original definition of bluegrass gives a certain preference to the

\footnotetext{
${ }^{236}$ Ibid., 187.

${ }^{237}$ Ibid., $187-188$.

${ }^{238}$ Ibid. 188.

${ }^{239}$ Ibid. 198.

${ }^{240}$ Ibid. 196-198.
} 
contribution of white musical sources. We now know though, that the roots of bluegrass music are just as much black as white. And though his focus is on defining bluegrass and not tracing its sources, it is still be beneficial to reexamine and expand Smith's work in light of this revelation.

Smith's first characteristic of bluegrass, for example, reads: "Bluegrass is hillbilly music: it is played by professional, white, Southern musicians, primarily for a Southern audience. It is stylistically based in Southern traditions." ${ }^{, 241}$ The truth of this statement is in general irrefutable - the majority of the bluegrass audience is white, most bluegrass musicians are white, and the music is based in Southern traditions. However, Smith is vague about the racial origins of these Southern traditions. In light of the evidence presented by this paper, it is perhaps more precise to say that the music is based in white as well as black Southern traditions. Smith does add later that the vocal style of bluegrass, its use of blues tonality, and blues song structure do come from black Southern traditions. ${ }^{242}$ This clarification though, leaves out the influence of other African-American styles such as black banjo playing, the black fiddle tradition, and the guitar style of Arnold Shultz.

The fourth characteristic that Smith identifies states that, "The integration of these instruments and voices in performance is more formalized and jazz-like than that encountered in earlier string band styles. Instruments function in three well defined roles, and each instrument changes roles according to predictable patterns." Later, Smith elaborates on this point, adding: "The marked rhythmic stress of the up-beat, the use of improvised solos whereby single musicians dominate the total sound, and the general pattern of ensemble integration are at base, African musical practices..."243 However, he went on to say that these African elements came

\footnotetext{
${ }^{241}$ Smith, 245.

${ }^{242}$ Ibid. 250.

${ }^{243}$ Ibid.
} 
into bluegrass through intermediary styles that developed outside of the Appalachian mountains: jazz and western swing. ${ }^{244}$ As we have seen though, these elements actually came into bluegrass through the hillbilly and Appalachian folk music that preceded it. The rhythmic elements that Smith identifies, the idea of collective improvisation, and the idea of ensemble integration came into mountain music through direct contact with African-American musicians and not through any other outside source.

Smith's description of bluegrass instrumentation lacks any reference to the origins of the five-string banjo or to that of the other instruments found in bluegrass bands. ${ }^{245}$ As explored above, the instruments in a bluegrass ensemble come from West Africa and Europe and reflect the diverse roots of the style itself. Smith's description of the playing styles of these instruments could also be expanded. Bluegrass guitar playing, for example, owes a great deal to the blues. Bluegrass fiddle playing is the result of interactions between black and white fiddlers as early as the seventeenth century. The mandolin style of Bill Monroe was influenced by traditional fiddle playing and also the blues he heard as a boy in Rosine, Kentucky. Scruggs's three-finger style also owes a debt to the white and black banjo pickers of North Carolina.

Smith's definition also seems somewhat deficient because when he wrote the article very little research had been done that documented the history of bluegrass music or traced its European and African sources. In fact, his definition of bluegrass came at a time when the style was just starting to be recognized as distinct from hillbilly music. However, we now have the benefit of the work done by Cantwell, Rosenberg, Conway, Farmelo, Malone, Lightfoot, and many others that fully traces the history and sources of bluegrass music. If we are ever to dispel the popular myth that bluegrass is and always has been a purely white music, new histories must

\footnotetext{
${ }^{244}$ Ibid.

${ }^{245}$ Ibid., 246.
} 
be crafted which incorporate the work of these later scholars with that of the older bluegrass writers like Smith, Ralph Rinzler, and Alan Lomax. As Farmelo put it: "The production of new narratives may help to disturb and uproot stereotypes which depend on certain versions of social history; possibly, the integration of new narratives and the disintegration of stereotypes, over time, will affect the social politics of pop music subcultures."246

It is my hope that this document can serve as a foundation for a new narrative of bluegrass, one that gives equal emphasis to the contributions of European Americans and those of African Americans. Though this paper merely scratches the surface of the history of the black and white interactions that led to bluegrass, I believe it demonstrates that these cultural exchanges lie at the heart of bluegrass music. As more research is done in this field, the myth that bluegrass is somehow the exclusive property of whites will eventually vanish. The music will be seen for what it truly is: a product of over three hundred years of black and white musical cooperation.

${ }^{246}$ Farmelo, 199. 


\section{BIBLIOGRAPHY}

\section{MONOGRAPHS, COLLECTIONS OF ESSAYS, AND LINER NOTES}

Adler, Thomas A. Bean Blossom: The Brown County Jamboree and Bill Monroe's Bluegrass Festivals. Urbana, IL: University of Illinois Press, 2011.

Cantwell, Robert. Bluegrass Breakdown: The Making of the Old Southern Sound. Urbana, IL: University of Illinois Press, 1984.

Cohen, Norm. Folk Music: A Regional Exploration. Westport, CT: Greenwood, 2005.

Conway, Cecelia. African Banjo Echoes in Appalachia. Knoxville: The University of Tennessee Press, 1995.

Conway, Cecelia and Betty N. Smith. Jane Hicks Gentry: A Singer Among Singers. Lexington, KY: University Press of Kentucky, 1998.

Cox, Bob L. and Archie Green. Fiddlin' Charlie Bowman: An East Tennessee Old-Time Music Pioneer and His Musical Family. Knoxville, TN: University of Tennessee, 2007.

Crawford, Richard. America's Musical Life: A History. New York: W. W. Norton, 2001.

Dickens, Hazel and Bill C. Malone. Working Girl Blues: The Life and Music of Hazel Dickens. Urbana, IL: University of Illinois Press, 2008.

Dotson-Lewis, B.L. The Sunny Side of Appalachia: Bluegrass from the Grassroots. West Conshohocken, PA: Infinity, 2008.

Duffy, Timothy, ed. Music Makers: Portraits and Songs of the Roots of America. Athens, GA: Hill Street, 2002.

Dunaway, Wilma A. Slavery in the American Mountain South. New York: Cambridge University, 2003.

English Folk Songs from the Appalachians: Comprising 122 Songs and Ballads and 323 Tunes. Comp. Olive Dame Campbell and Cecil J. Sharp. New York: G.P. Putnam's Sons, 1917.

Epstein, Dena J., Sinful Tunes and Spirituals: Black Folk Music to the Civil War. Urbana and Chicago: University of Illinois Press, 2003. 
Ewing, Tom, ed. The Bill Monroe Reader. Urbana, IL: University of Illinois Press, 2000.

Floyd, Samuel A., Jr. The Power of Black Music. New York: Oxford Press, 1995.

Glass, Paul and Louis C. Singer. Songs of Hill and Mountain Folk. New York: Grosset \& Dunlap, 1967.

Goldsmith, Thomas, ed. The Bluegrass Reader. Urbana, IL: University of Illinois Press, 2004.

Harvey, Steven. Bound for Shady Grove. Athens, GA: University of Georgia Press, 2000.

Huber, Patrick. Lint Head Stomp: The Creation of Country Music in the Piedmont. Chapel Hill: The University of North Carolina Press, 2008.

Irwin, John Rice. A People and their Music: The Story Behind The Story of Country Music. Atglen, PA: Schiffer, 2000.

Jones, Loyal and John M. Forbes. Minstrel of the Appalachians: The Story of Bascom Lamar Lunsford. Lexington, KY: University Press of Kentucky, 2002.

Kodish, Debora. Good Friends and Bad Enemies: Robert Winslow Gordon and the Study of American Folksong. Urbana, IL: University of Illinois Press, 1986.

Krehbiel, Henry Edward. Afro-American Folksongs: A Study in Racial and National Music New York: F. Ungar, 1913, 1974.

Lambert, Jake with Curly Sechler. Biography of Lester Flatt: "The Good Things Outweigh the Bad." Hendersonville, Tennessee: Jay-Lyn Publications, 1982.

Ledgin, Stephanie P. Homegrown Music: Discovering Bluegrass. Westport, CT: Praeger, 2004.

Lornell, Kip. Introducing American Folk Music: Ethnic and Grassroot Traditions in the United States. New York, McGraw Hill, 2002.

Malone, Bill C., Country Music U.S.A. Austin, TX: University of Texas Press, 1985, rev. 2002.

McGee, Marty. Traditional Musicians of the Central Blue Ridge: Old Time, Early Country, Folk and Bluegrass Label Recording Artists, With Discographies. Jefferson, NC: McFarland, 2000 .

Rinzler, Ralph. Liner notes to American Banjo Scruggs Style. Various Artists. Smithsonian Folkways SFW40037. CD. 1990.

Rooney, James. Bossmen: Bill Monroe and Muddy Waters. New York: Hayden Book Company, 1971.

Rosenberg, Neil V. Bluegrass: A History. Chicago: University of Illinois Press, 1985. 
Rosenberg, Neil V., and Charles K. Wolfe. The Music of Bill Monroe. Urbana, IL: University of Illinois Press. 2007.

Stanley, Ralph, and Eddie Dean. Man of Constant Sorrow: My Life and Times. New York: Gotham 2009.

Whisnant, David E. All That Is Native and Fine: The Politics of Culture in An American Region. Chapel Hill, NC: University of North Carolina Press, 1983.

Wolfe, Charles K. Kentucky Country: Folk and Country Music of Kentucky. Lexington, KY: University Press of Kentucky, 1982.

Yates, Mike, Elaine Bradtke, Malcolm Taylor, and David Atkinson eds., Dear Companion: Appalachian Traditional Songs and Singers from the Cecil Sharp Collection. London: English Folk Dance and Song Society, 2004.

\section{ARTICLES IN PERIODICALS AND LINER NOTES}

Alden, Ray. "Kimbels a Wagoners: Mountain Music Families." Old Time Music 42 (January 1, 1985): 11-12.

Alexander, George. "Traditional Music in the Appalachian Mountains." English Dance and Song 30, no. 3 (June 1, 1968): 62-64.

Allen, R. Raymond. "The Fiddle Tradition in Central Pennsylvania." Pennsylvania Folklife 31, no. 2 (January 1, 1981): 50-55.

Armstrong, Randal. "The Adaptable Appalachia Dulcimer." Music Educators Journal 66, no. 6 (February 1, 1980): 38-41.

Bevil, J. Marshall. "Scale in Southern Appalachian Folksong: A Reexamination." College Music Symposium 26 (January 1, 1986): 77-91.

Blackley, Becky. "The Autoharp: History and Place in Bluegrass." Bluegrass Breakdown: The Official Publication of The California Bluegrass Association 9, no. 1 (January 1, 1983): 615.

Burton, Thomas G. "The Lion's Share: Scottish Ballads in Southern Appalachia." Tennessee Folklore Society Bulletin 58, no. 3 (January 1, 1997): 95-101.

Burton, Thomas G., and Ambrose Manning. "A Checklist of Child Ballad Variants Found in Southern Appalachia." Tennessee Folklore Society Bulletin 58, no. 3 (January 1, 1997): $102-116$. 
Cohen, Norman. "The Skillet Lickers: A Study of a Hillbilly String Band and its Repertoire," Journal of American Folklore, 78. no. 309, Hillbilly Issue (July - September, 1965): 229244.

Conway, Cecelia. "Black Banjo Songsters in Appalachia." Black Music Research Journal 23, no. 1-2 (March 1, 2003): 149.

. "Mountain Echoes of the African Banjo." Appalachian Journal 20, no. 2 (January 1, 1993): 146-161.

Daniel, Wayne. "Making a Joyful Noise Unto the Lord: The Gospel Roots of Bluegrass." Bluegrass Unlimited 19, no. 9 (March 1, 1985): 58-62.

Eagle, Bob. "Directory of African-Appalachian Musicians." Black Music Research Journal 24, no. 1 (March 1, 2004): 7-71.

. "Predicting Black Musical Innovation and Integration: The 1850 Mance Index for Appalachia." Black Music Research Journal 24, no. 1 (March 1, 2004): 73-90.

Farmelo, Allen. "Another History of Bluegrass: The Segregation of American Popular Music, 1820-1900." Popular Music And Society 25, no. 1-2 (March 1, 2001): 179-203.

Freed, Mark. "Preliminary Bibliography of Best-Known Black Appalachian Musicians." Black Music Research Journal 24, no. 1 (March 1, 2004): 91-169.

Green, Archie. “The Carter Family's 'Coal Miner's Blues'.” Southern Folklore Quarterly, 25 (1961): 226-237.

Hay, Fred J. "Black Musicians In Appalachia: An Introduction to Affrilachian Music." Black Music Research Journal 23, no. 1-2 (March 1, 2003): 1-19.

Langrall, Peggy. "Appalachian Folk Music: From Foothills to Footlights." Music Educators Journal 72, no. 7 (March 1, 1986): 37-39.

Lawrence, Keith. “Arnold Shultz: Godfather of Bluegrass?” Bluegrass Unlimited, 24 (November 1989): 39-43.

Leftwich, Brad. "Reflections of Southern Appalachian Fiddling." Fiddler Magazine 2, no. 4 (January 1, 1995): 4-9.

Lightfoot, William E. "The Three Doc(k)s: White Blues in Appalachia." Black Music Research Journal 23, no. 1-2 (March 1, 2003): 167-193.

Matteson, Richard L., Jr. "Folksongs from the Appalachians." Guitar Review no. 89 (March 1, 1992): 10-13. 
Olson, Ted. "A Ballad Collector Extraordinaire Comes to the Mountains." Appalachian Heritage 19, no. 1 (January 1, 1991): 20-26.

Pearson, Barry Lee. "Appalachian Blues." Black Music Research Journal 23, no. 1-2 (March 1, 2003): 23-51.

Pestcoe, Shlomo. "On the Trail of Lost Roots." Sing Out! The Folk Song Magazine 34, no. 1 (January 1, 1989): 14-19.

Phillips, Stacy. "Evolution of Bluegrass Fiddle." Fiddler Magazine 1, no. 4 (January 1, 1994): 1316.

Scherman, Tony. "A Man Who Mined Musical Gold in the Southern Hills." Smithsonian 16, no. 1 (April 1, 1985): 173-196.

Smith, Mayne L. “An Introduction to Bluegrass.” Journal of American Folklore. 78, no. 309 (Jul. Sep. 1965): 245-256.

Spottswood, Richard K. "Country Music and the Phonograph." Bluegrass Unlimited 21, no. 8 (February 1, 1987): 17-23.

Straw, Richard. "Appalj interview: Mike Seeger and Hazel Dickens." Appalachian Journal 13, no. 4 (June 1, 1986): 410-425.

Wells, Paul F. "Fiddling as an Avenue of Black-White Musical Interchange." Black Music Research Journal 23, no. 1-2 (March 1, 2003): 135-147.

Winans, Robert B. "The Folk, the Stage, and the Five-String Banjo in the Nineteenth Century," Journal of American Folklore, 89, no. 354 (Oct. - Dec., 1976): 407-437.

Winans, Robert B. and Elias J. Kaufman. "Minstrel and Classic Banjo: American and English Connections." American Music, 12, no.1 (Spring 1994): 1-30.

Wolfe, Bobby. "America's 2nd Native Instrument: The Bluegrass Dobro." Bluegrass Unlimited 22, no. 7 (January 1, 1988): 17-24.

Zolten, Jerry. "Movin' The Mountains: An Overview of Rhythm and Blues and its Presence in Appalachia." Black Music Research Journal 23, no. 1-2 (March 1, 2003): 67-89.

\section{PAPERS IN COLLECTED WORKS AND ENCYCLOPEDIA ENTRIES}

Allen, Ray. "Performing Dio's legacy: Mike Seeger and the Urban Folk Music Revival." In Ruth Crawford Seeger's Worlds: Innovation and Tradition in Twentieth-Century American Music, ed. Ellie M. Hisama and Ray Allen, 224-251. Rochester: University of Rochester, 2007. 
Barraclough, Nick, and Kurt Wolff. "USA: Bluegrass and Old-Time-High an' Lonesome." In Collected Work: World Music: The Rough Guide. II: Latin and North America, Caribbean, India, Asia and Pacific, ed. Simon Broughton and Mark Ellingham, 536-551. London: Rough Guides, 2000.

Brose, David A. “Old-time Music.” In Encyclopedia of Appalachia Online accessed 2 Apr 2013, $<\mathrm{http}: / /$ www.encyclopediaofappalachia.com/entry.php?rec $=162>$

Carrigan, Henry L., Jr. “Bluegrass.” In Encyclopedia of Gospel Music, ed. W.K. McNeil. New York: Routledge, 2005.

Carter, Thomas. "I Never Could Play Alone': The Emergence of the New River Valley String Band, 1875-1915." In Arts in Earnest: North Carolina Folklife, ed. Daniel Patterson and Charles Zug III Durham, N.C. : Duke University Press, 1990: 47-74.

Conway, Cecelia. "Banjo.” In Encyclopedia of Appalachia Online, accessed 1 Apr 2013, $<\mathrm{http}$ :/www.encyclopediaofappalachia.com/entry.php?rec=32>

Lightfoot, William E. “A Regional Musical Style: The Legacy of Arnold Shultz.” In Sense of Place: American Regional Cultures, ed. Barbara Allen and Thomas J. Schlereth, 120-137. Lexington: University Press of Kentucky, 1990.

Lomax, Alan. "Bluegrass Background: Folk Music with Overdrive." In Alan Lomax: Selected Writings (1934-1997), ed. Ronald D. Cohen, 200-202. New York: Routledge, 2003.

Malone, Bill C. "Western Swing.” In Grove Music Online. Oxford Music Online, accessed 23 September 2012.

$<$ http://www.oxfordmusiconline.com/subscriber/article/grove/music/30173>

McCarthy, William Bernard. "Olive Dame Campbell and Appalachian Tradition." In Ballads into Books: The Legacies of Francis James Child, ed. Tom Chessman and Rieuwerts Sigrid, 6980. Bern: Peter Lang, 1997.

McCullough, Maxwell. "The Mandolin in Twentieth-Century America: An Instrument in Search of an Identity." In Mandolin Orchestras of North America: Year 2000, ed. Norman Levine, 15. Arlington, VA: Plucked String, 2000.

Phillips, John Edward. "The African Heritage of White America," In Africanisms in American Culture, ed. Joseph E. Holloway, Bloomington: Indiana University Press, 1991.

Rosenberg, Neil V. "Blue Moon of Kentucky: Bill Monroe, Flatt \& Scruggs, and the Birth of Bluegrass." In Country: The Music and the Musicians, ed. Paul Kingsbury, and Alan Axelrod, 186-221. New York: Abbeville, 1988.

Tallmadge, William H. "The Folk Banjo and Clawhammer Performance Practice in the Upper South: A Study of Origins." In The Appalachian Exeperience, ed. Barry M. Buxton, 168179. Boone, North Carolina: Appalachian Consortium, 1989. 
Titon, Jeff Todd. "Fiddle.” In Encyclopedia of Appalachia Online, accessed 1 Apr 2013, $<$ http://www.encyclopediaofappalachia.com/entry.php?rec=80>

Turner, William H. "The Demography of Black Appalachia: Past and Present." In Blacks in Appalachia, ed. William H. Turner and Edward J. Cabbell. Lexington: University of Kentucky Press, 1985.

Weisberger, Jon. "Rocky Road Blues: Bluegrass Music's Up and Down Journey." In Will the Circle be Unbroken: Country Music in America, ed. Alanna Nash and Paul Kingsbury, 186-213. New York: DK Pub, 2006.

\section{DISSERTATIONS}

Miyake, Mark Y. "The Discourse on Race within the Bluegrass Music Community." Ph.D. diss., Indiana University, 2009.

Noakes, Jennie. "'From the Top of the Mountain': Traditional Music and the Politics of Place in the Central Appalachian Coalfields." Ph.D. diss., University of Pennsylvania, 2008.

Rockwell, Joti. "Drive, Lonesomeness, and the Genre of Bluegrass Music." Ph.D. diss., University of Chicago, 2007. 